\title{
A functional group oxidation model (FGOM) for SOA formation and aging
}

\author{
X. Zhang ${ }^{1}$ and J. H. Seinfeld ${ }^{1,2}$ \\ ${ }^{1}$ Division of Engineering and Applied Science, California Institute of Technology, Pasadena, CA, USA \\ ${ }^{2}$ Division of Chemistry and Chemical Engineering, California Institute of Technology, Pasadena, CA, USA
}

Correspondence to: J. H. Seinfeld (seinfeld@caltech.edu)

Received: 28 November 2012 - Published in Atmos. Chem. Phys. Discuss.: 18 December 2012

Revised: 30 April 2013 - Accepted: 20 May 2013 - Published: 18 June 2013

\begin{abstract}
Secondary organic aerosol (SOA) formation from a volatile organic compound (VOC) involves multiple generations of oxidation that include functionalization and fragmentation of the parent carbon backbone and likely particlephase oxidation and/or accretion reactions. Despite the typical complexity of the detailed molecular mechanism of SOA formation and aging, a relatively small number of functional groups characterize the oxidized molecules that constitute SOA. Given the carbon number and set of functional groups, the volatility of the molecule can be estimated. We present here a functional group oxidation model (FGOM) that represents the process of SOA formation and aging. The FGOM contains a set of parameters that are to be determined by fitting of the model to laboratory chamber data: total organic aerosol concentration, and $\mathrm{O}: \mathrm{C}$ and $\mathrm{H}: \mathrm{C}$ atomic ratios. The sensitivity of the model prediction to variation of the adjustable parameters allows one to assess the relative importance of various pathways involved in SOA formation. An analysis of SOA formation from the high- and low- $\mathrm{NO}_{\mathrm{x}}$ photooxidation of four $\mathrm{C}_{12}$ alkanes ( $n$-dodecane, 2methylundecane, hexylcyclohexane, and cyclododecane) using the FGOM is presented, and comparison with the statistical oxidation model (SOM) of Cappa et al. (2013) is discussed.
\end{abstract}

\section{Introduction}

Development of a predictive model for secondary organic aerosol (SOA) formation and evolution represents one of the most challenging problems in atmospheric chemistry. In principle, the benchmark for describing SOA formation is a fully explicit chemical model based on a complete multigeneration gas-phase oxidation mechanism for the parent VOC. A quintessential example is GECKO-A, in which an exhaustive gas-phase VOC oxidation mechanism is generated automatically based on chemical kinetic and mechanistic specifications (Aumont et al., 2005; Camredon et al., 2007; Lee-Taylor et al., 2011; Aumont et al., 2012). Vapor pressures are estimated (based on group-contribution methods) for each of the thousands of products generated in the mechanism, from which gas-particle partitioning equilibrium constants are computed. The overall yield of SOA for the system as well as its complete chemical makeup are predicted. In such an explicit model, the predictions depend critically on the chemical rules and reaction rate constants imbedded in the mechanism. For the types of highly functionalized compounds involved in SOA formation, experimentally verified rate constants and mechanisms are generally available for only the first few steps of oxidation. Nonetheless, an explicit model like GECKO-A or MCM 3.1 (Jenkin et al., 1997; Saunders et al., 2003; Bloss et al., 2005) embodies the current state of understanding of atmospheric reaction mechanisms. The molecular vapor pressure prediction method used also plays an important role in the overall SOA yield predicted (Valorso et al., 2011), although this is the case for any SOA model incorporating specific or lumped gas-phase photochemical mechanisms. Whereas it is desirable to embody within a model as much basic understanding of the SOA formation and evolution process as possible, it is necessary to keep in mind that an important goal of SOA model development is a computational module that can be included in 3-D atmospheric chemical transport models. Consequently, 
the challenge is to balance the desire for chemical fidelity with the need for computational feasibility.

Aerosol mass spectrometer (AMS) measurements of organic aerosols, now a routine component of atmospheric measurements and chamber experiments, enable derivation of the atomic $\mathrm{O}: \mathrm{C}$ and $\mathrm{H}: \mathrm{C}$ ratios of SOA, from which one can infer its overall oxidation state (Kroll et al., 2011). The volatility of SOA is not generally measured routinely, although the volatility of the organic mixture is an essential property of SOA formation. Any SOA model requires a prediction of aerosol volatility, which is related to the molecular properties of the components comprising the SOA, as embodied, for example, in carbon number and oxidation state. The relationship between oxidation state and volatility is not unique; that is, molecular mixtures with the same overall oxidation state do not necessarily exhibit the same overall volatility.

The traditional approach to representing SOA formation, as embodied in the 2-product model (Odum et al., 1996), is based on fitting an empirical gas-particle partitioning model to chamber SOA yield data as a function of the mass concentration of absorbing aerosol. The volatility basis set (VBS) (Donahue et al., 2006) is an extension of the 2-product concept, in which VOC oxidation products are assigned to volatility "bins" spanning the range of ambient organic effective saturation mass concentrations $\left(\mathrm{C}^{*}\right)$. As the oxidation products undergo multi-generation reaction (often referred to as "aging"), each generation of reaction products is assigned to a volatility class (Robinson et al., 2007). The extent of gas-particle partitioning associated with each volatility bin depends on both the $\mathrm{C}^{*}$ of that class and the total mass concentration of the absorbing medium $\left(M_{\mathrm{o}}\right)$. The stoichiometric assignments of oxidation products to volatility classes are determined through fitting the model to chamber data.

Compelling evidence exists from field observations that current SOA models consistently underpredict ambient organic aerosol concentration (Tsigaridis and Kanakidou, 2003; Heald et al., 2005, 2006; Volkamer et al., 2006; Jimenez et al., 2009). Such underprediction is almost certainly a result of a number of factors. First, the traditional SOA models on which these earlier modeling studies are based generally do not account explicitly for degree of oxidation and aging, aspects that are key to prediction of SOA formation. Second, the laboratory chamber data on which current models are based generally do not exhibit the degree of oxidation observed in atmospheric organic aerosol. Finally, the VOC and POA emission inventories that drive atmospheric models in all likelihood understate the fluxes of key SOA-forming species.

Three recent studies have been directed at a next generation of SOA models. Pankow and Barsanti (2009) introduced the "carbon number-polarity grid" (CNPG) framework. They expanded the "2-product" concept to the " $n \mathrm{p}+m \mathrm{P}$ " approach ( $n$ products with $m$ possible types of very low volatility compounds) to represent the lumped oxidation and accre- tion products (Barsanti et al., 2011). Three levels of reactions (the oxidation of parent hydrocarbon and $n$ products, and the formation of $m$ particle-phase compounds) are included to represent the complexity of the mix of condensable primary and secondary compounds as a function of time. Donahue et al. (2011, 2012a, b) developed the 2-D volatility basis set (2D-VBS) employing saturation mass concentration and the degree of oxidation (The average oxidation state of aerosol, $\mathrm{OS}_{\mathrm{C}}(2 \times \mathrm{O}: \mathrm{C}-\mathrm{H}: \mathrm{C})$, can be used interchangeably with the $\mathrm{O}: \mathrm{C}$ ratio) to describe the coupled aging and phase partitioning of organic aerosol. A point in the 2-D space represents an ensemble of molecules with the same $\mathrm{C}^{*}$ and $\mathrm{OS}_{\mathrm{C}}$. In the 2-D VBS space, if the number of carbon atoms, $n_{\mathrm{C}}$, in the carbon backbone does not change during oxidation, products will form along lines of constant $n_{\mathrm{C}}-$ i.e., lines extending from the lower right (high $\mathrm{C}^{*}$ vs. low $\mathrm{OS}_{\mathrm{C}}$ ) to the upper left (low $\mathrm{C}^{*}$ vs. high $\mathrm{OS}_{\mathrm{C}}$ ). When chamber data are available, the volatility distribution of the products is obtained by SOA mass yield fitting. The products are spread over the $\mathrm{OS}_{\mathrm{C}}$ coordinate to produce a distribution that matches bulk AMS data and any known products. Cappa and Wilson (2012) formulated the statistical oxidation model (SOM) that describes SOA formation as a statistical evolution in the space of numbers of carbon and oxygen atoms, $n_{\mathrm{C}}$ and $n_{\mathrm{O}}$, with fitting parameters that govern the probability of fragmentation vs. functionalization, the number of oxygen atoms added per functionalization reaction, and the decrease in vapor pressure accompanying addition of an oxygen atom.

The new generation of models, as exemplified by the 2DVBS and the SOM, represents SOA formation and evolution in terms of the competition between functionalization and fragmentation, the extent of oxygen atom addition, and the change of volatility. As in the earlier generation of SOA models, predictions can be adjusted to fit laboratory chamber data by determination of the optimal values of a number of parameters in the model. (This is in contrast to the fully explicit chemical model, for which rate constants and branching ratios are generally specified a priori based, for example, on structure-activity relationships.) We present here a new variation of the SOA model that is based on explicit chemical information in terms of the types of functional groups that result from the oxidation of a parent VOC. We term this the functional group oxidation model (FGOM). As in the 2D-VBS and the SOM, the FGOM is characterized by a set of parameters that are determined by analysis of chamber data. Key issues that must be addressed in SOA model development include the following: (1) in fragmentation, does $\mathrm{C}-\mathrm{C}$ bond scission occur at any of the $\mathrm{C}-\mathrm{C}$ bonds in the molecule or does the model specify, for example, that fragmentation always produces $\mathrm{C}_{1}$ and $\mathrm{C}_{n-1}$ ? (2) How important are particle-phase reactions to the evolution of SOA, and how is such chemistry represented? (3) To what extent does particle-phase chemistry increase the oxidation state of the aerosol and what is its effect on particle volatility? 
Such issues have important implications for simulations of the overall mass concentration of SOA and its oxidation state.

We first describe the development of the FGOM, and then apply it to SOA formation from the low- and high- $\mathrm{NO}_{\mathrm{x}}$ photooxidation of four $\mathrm{C}_{12}$ alkanes. An important aspect of the present work is a comparison of the FGOM to the SOM, both of which are built on a similar foundation. It turns out that, even with the number of adjustable parameters, complete matching to organic aerosol mass concentration and $\mathrm{O}: \mathrm{C}$ and $\mathrm{H}: \mathrm{C}$ ratios over the course of an oxidation is challenging. Assessing the sensitivity of predictions to assumptions made in the model development is crucial in interpreting results of its application.

\section{Development of a functional group oxidation model (FGOM)}

SOA formation from a parent VOC involves multiple generations of oxidation coupled to gas-particle partitioning. Note that a "generation" is simply the number of times that a molecule has reacted with oxidants $\left(\mathrm{OH}, \mathrm{O}_{3}\right.$, or $\left.\mathrm{NO}_{3}\right)$, starting from the parent VOC. In the general process depicted in Fig. $1, S_{i}^{\mathrm{g}}$ represents the spectrum of gas-phase products at the $i$-th generation, each product having its own chemical identity and volatility. The multi-generation progression of the chemistry is characterized by a competition between functionalization and fragmentation. Each $S_{i}^{\mathrm{g}}$ may, in principle, partition to the aerosol phase, $S_{i}^{\mathrm{p}}$. Once in the aerosol phase, $S_{i}^{\mathrm{p}}$ may itself undergo chemical reaction. In Fig. 1, these reactions are assumed to parallel mechanistically those in the gas phase, although that assumption need not be invoked. The particle-phase species may be converted to essentially nonvolatile compounds, denoted $N^{\mathrm{p}}$ by reactions that can be either nonoxidative or oxidative in nature (Kroll and Seinfeld, 2008). The nonoxidative reactions are typified by the association of two condensed-phase organic molecules.

The schematic in Fig. 1 defines the overall structure of the functional group oxidation model (FGOM). We term the model FGOM, in that a comprehensive chemical mechanism, such as MCM 3.1 or GECKO-A, is used to predict the types of functional groups that characterize the oxidation of the parent organic molecule, yet the detailed mechanism is not employed in the model itself. With the carbon number and the spectrum of functional groups specified, the vapor pressure of the compound defines the relationship between $S_{i}^{\mathrm{g}}$ and $S_{i}^{\mathrm{p}}$. Because the full chemical mechanism of SOA formation is not generally known, predictive SOA models built upon chamber data are characterized by a set of parameters the values of which are determined by optimal fitting to experimental data. Gas-phase oxidant (e.g., $\mathrm{OH}, \mathrm{O}_{3}$, and $\mathrm{NO}_{3}$ ) concentrations need to be specified based on chamber conditions. The quantitative behavior of the FGOM is expressed by a set of kinetic equations for $S_{i}^{\mathrm{g}}, S_{i}^{\mathrm{p}}$, and $N^{\mathrm{p}}$.

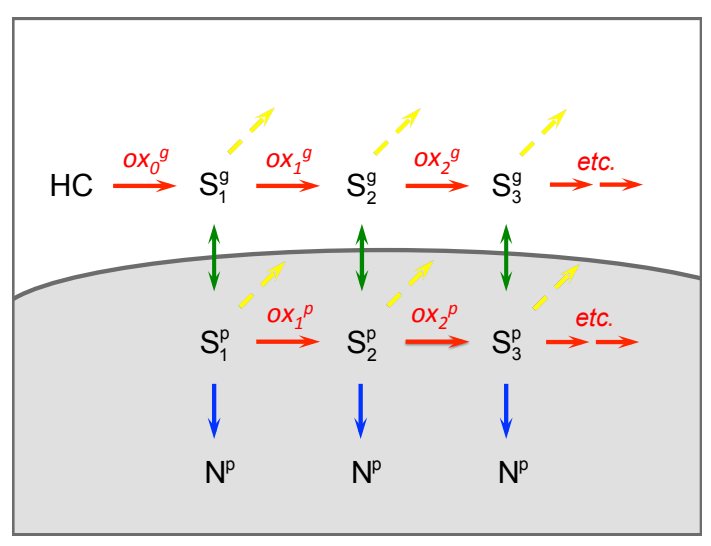

Fig. 1. Scheme for SOA formation and evolution, showing multigenerational gas- and particle-phase reactions, in the functional group oxidation model. "S" and "N" denote semivolatile and nonvolatile compounds, respectively. Note that the single product for each generation shown here represents a spectrum of products spanning a range of volatilities and oxidation states. The oxidation of semivolatile compounds comprises two processes: functionalization (red arrows) and fragmentation (yellow arrows). Instantaneous equilibrium partitioning is assumed (green arrows). Nonoxidative (accretion) reactions are considered as bimolecular irreversible reactions (blue arrows).

\subsection{Functionalization}

The essential nature of functionalization is the addition, for a particular parent VOC, of a certain number and type of functional groups at each generation of reaction. The mechanism underlying the addition of different functional groups is guided by the specific chemistry. More than one functional group can be added per generation, and the types of functional groups added vary by generation. Reaction rate constants for different functionalization steps are lumped according to the structure of the parent VOC molecule and the chemical transformation of different functional groups based on structure-activity relationships (Kwok and Atkinson, 1995). For purpose of discussion, one can consider $\mathrm{OH}$ reaction as the oxidative process in SOA formation, although, if appropriate, other oxidants such as $\mathrm{O}_{3}$ and $\mathrm{NO}_{3}$ can be considered as well. Consideration of the general mechanism of $\mathrm{OH}$ oxidation allows one to identify the types of functional groups involved. OH-initiated oxidation leads to a peroxy radical $\left(\mathrm{RO}_{2}\right)$, the fate of which controls the SOA-forming mechanism (Kroll and Seinfeld, 2008). At sufficiently low $\mathrm{NO}_{\mathrm{x}}$ concentrations, $\mathrm{RO}_{2}$ self-reactions will dominate the fate of $\mathrm{RO}_{2}$ :

$$
\begin{aligned}
\mathrm{RO}_{2}+\mathrm{HO}_{2} & \rightarrow \mathrm{ROOH}+\mathrm{O}_{2} \\
\mathrm{RO}_{2}+\mathrm{RO}_{2} & \rightarrow 2 \mathrm{RO}+\mathrm{O}_{2} \\
& \rightarrow \mathrm{RCHO}+\mathrm{ROH} \\
& \rightarrow \mathrm{ROOR}+\mathrm{O}_{2} .
\end{aligned}
$$


In the presence of sufficient $\mathrm{NO}_{\mathrm{x}}, \mathrm{RO}_{2}$ reacts preferentially with $\mathrm{NO}$ and $\mathrm{NO}_{2}$ - for example,

$$
\begin{aligned}
\mathrm{RO}_{2}+\mathrm{NO} & \rightarrow \mathrm{RO}+\mathrm{NO}_{2} \\
& \rightarrow \mathrm{RONO}_{2} .
\end{aligned}
$$

Alkoxy radicals (RO) formed either isomerize through a $1,5 \mathrm{H}$-atom shift to a $\delta$-hydroxyalkyl radical, which introduces an extra $\mathrm{OH}$ group, react with $\mathrm{O}_{2}$ to form carbonyls, or undergo fragmentation. Thus, functional groups introduced from peroxy radical reactions include hydroperoxide $(-\mathrm{OOH})$, nitrate $\left(-\mathrm{ONO}_{2}\right)$, hydroxyl $(-\mathrm{OH})$, and carbonyl $(-\mathrm{C}=\mathrm{O})$. If the parent hydrocarbon contains a nonaromatic ring, decomposition of the RO will not lead to a decrease of carbon number. The addition of $\mathrm{OH}$ introduces an extra hydroxyl group to the parent hydrocarbon. Addition of $\mathrm{OH}$ to an aromatic ring is mechanistically different from that to a $\mathrm{C}=\mathrm{C}$ bond. The progressive photochemical reactions of oxidation products proceed by the following: (1) H-atom abstraction from $\mathrm{C}-\mathrm{H}$ bonds and, to a lesser extent, from the $\mathrm{O}-$ $\mathrm{H}$ bond of alcohols; (2) $\mathrm{H}$-atom abstraction from $\mathrm{C}-\mathrm{H}$ bonds of carbonyls; (3) oxidation of $-\mathrm{OOH}$ and $-\mathrm{ONO}_{2}$ groups; and (4) photolysis of $-\mathrm{OOH}$ and $-\mathrm{ONO}_{2}$ groups.

The addition of various combinations of these four groups via photochemical oxidation accounts for a majority of the gas-phase reactions involving semivolatile product aging. This assumption is based on observations pertinent to the photooxidation of VOCs and IVOCs (alkanes, alkenes, terpenes, and aromatics). Progressive gas-phase oxidation of VOC leads to the formation of oxygenated products that include alcohol, ketone, aldehyde, carboxylic acid, alkyl nitrate, hydroperoxide, and/or peroxyacyl nitrate functional groups (Atkinson, 2000). Additional functionalities, such as ether and ester groups, are also found in smaller amounts. Most of these moieties are assumed to be represented by a combination of the four surrogate functional groups with comparable chemical identities (volatility and oxidation state): (1) carbonyl and aldehyde share similar chemical and physical properties. The decreases of the logarithm of vapor pressure upon the addition of $-\mathrm{CHO}$ and $-\mathrm{C}=\mathrm{O}$ are predicted by SIMPOL. 1 to be 1.3196 and 0.9364 , respectively. In EVAPORATION, these two functional groups have the same contribution $(\triangle \mathrm{LVP}=1.1951)$ to the vapor pressure decrease. (2) Carboxylic acid can be represented by the sum of $-\mathrm{C}=\mathrm{O}$ and $\mathrm{OH}$. Based on the prediction of SIMPOL.1, the decrease of the logarithm of vapor pressure upon the addition of one $-\mathrm{C}(\mathrm{O}) \mathrm{OH}$ group is 3.5121 , which is roughly similar to the sum of $\triangle \mathrm{LVP}$ values, 3.3114 , upon the addition of one $-\mathrm{OH}(\Delta \mathrm{LVP}=2.1834)$ and one $-\mathrm{C}=\mathrm{O}(\Delta \mathrm{LVP}$ $=1.1280)$ group. The increase of oxidation state resulting from the addition of $-\mathrm{C}(\mathrm{O}) \mathrm{OH}$ or the sum of $-\mathrm{OH}$ and $-\mathrm{C}=\mathrm{O}$ is the same - i.e., $6 / n_{\mathrm{C}}$. In view of this, the formation of a carboxylic group, which results from the $\mathrm{H}$-atom abstraction from aldehyde, can be considered as the addition of a $-\mathrm{OH}$ group onto a carbonyl group. (3) The contribution of an ether group to vapor pressure is close to that from carbonyl. Epoxides have been observed from the photooxidation of isoprene under low- $\mathrm{NO}_{\mathrm{x}}$ conditions (Paulot et al., 2009). The contribution of the formation of an epoxide group to $\triangle \mathrm{LVP}$ and $\Delta \mathrm{OS}_{\mathrm{C}}$ are $\sim 0.7948$ and $4 / n_{\mathrm{C}}$, respectively, compared with 1.1280 and $4 / n_{C}$ by the addition of one $-\mathrm{C}=\mathrm{O}$ group. Note that the structure-property relationships used in vapor pressure prediction models are more complicated (Camredon and Aumont, 2006) and the vapor pressures of a large subset of organics in the atmosphere cannot be simply represented by the four functional groups identified in this study. The functionalization channel in FGOM is a generalized predictive technique that is intended to capture key processes. The set of functional groups in FGOM that characterize the progressive oxidation reactions can, in principle, be expanded and updated for different hydrocarbon systems.

Particle-phase oxidative reactions can occur via heterogeneous $\mathrm{OH}$ uptake to particles and $\mathrm{OH}$-initiated oxidation in the bulk (e.g., Ravishankara, 1997; Knopf et al., 2005; Zahardis and Petrucci, 2007; Shiraiwa et al., 2011). As noted, we will assume that particle-phase oxidation reactions proceed in parallel with and via the same chemical mechanisms as in the gas phase. The reaction rate of $\mathrm{OH}$ oxidation of compound " $\mathrm{X}$ " in the particle phase can be expressed as

$$
\frac{d[\mathrm{X}]_{\mathrm{p}}}{\mathrm{d} t}=k_{\mathrm{p}}^{\prime}[\mathrm{X}]_{\mathrm{p}},
$$

where $k_{\mathrm{p}}^{\prime}$, the pseudo first-order particle-phase reaction rate constant, is related to the corresponding gas-phase reaction by $k_{\mathrm{p}}^{\prime}=r_{\mathrm{p}} k_{\mathrm{g}}[\mathrm{OH}]_{\mathrm{g}}$. From this, $k_{\mathrm{g}}$ is the corresponding gasphase bimolecular reaction rate constant, $[\mathrm{OH}]_{\mathrm{g}}$ is the gasphase $\mathrm{OH}$ radical concentration, and $r_{\mathrm{p}}$ is the ratio of the $\mathrm{OH}$ reaction rate constant in the particle phase to that in the gas phase. $r_{\mathrm{p}}$ is one of the free parameters of the model. Since particle size dependence of the kinetic parameters is not considered in the model, size dependence of $r_{\mathrm{p}}$ is not accounted for.

\subsection{Fragmentation}

More heavily oxidized molecules can fragment more easily (Kroll et al., 2009). Fragmentation thus tends to lead to a reduction in the ability to form organic aerosol. The probability of fragmentation $f$ for a stable molecule has been proposed to be represented as a function of the $\mathrm{O}: \mathrm{C}$ ratio of the molecule (Jimenez et al., 2009; Murphy et al., 2011, 2012; Cappa and Wilson, 2012; Chacon-Madrid et al., 2012; Donahue et al., 2012b):

$f=(\mathrm{O}: \mathrm{C})^{f_{v}}$,

where $f_{v}$ is a parameter to be determined by fitting of data. Fragmentation does not necessarily substantially change the average $\mathrm{O}: \mathrm{C}$ ratio of SOA; fragmentation leads to products with fewer carbon and, generally, more oxygen atoms, although the ultimate contribution of these products to the SOA 
mass depends on their volatilities. Species with a higher O : C ratio have a greater probability of fragmentation. In this way, $f_{v}$ is a key factor that influences the total organic aerosol mass concentration.

In the SOA model structure, it is necessary to make an assumption concerning the mechanism of fragmentation. In the SOM, the distribution of fragments is computed in two alternative ways: (1) a random probability for the location of the $\mathrm{C}-\mathrm{C}$ bond scission, thus affecting the resulting size of the scission product; and (2) fragmentation leads to production of only $\mathrm{C}_{1}$ species, along with the appropriate co-product. Cappa and Wilson (2012) found that the "random fragmentation" and the "one carbon loss fragmentation" yield a very similar set of optimal parameters for chamber-generated $\alpha$ pinene SOA. The 2-D VBS assumes that the $\mathrm{C}-\mathrm{C}$ bond scission from the precursor is randomly distributed along the carbon backbone. The distribution of products over the $\mathrm{OS}_{\mathrm{C}}-n_{\mathrm{C}}$ space is computed in such a way that the less volatile bins to the left of the midpoint bin (nominally $\mathrm{C}_{n / 2}$ ) have the same $\mathrm{O}: \mathrm{C}$ as the precursor, while the more volatile bins to the right of the midpoint bin progress diagonally towards the bin with highest $\mathrm{O}: \mathrm{C}$ (i.e., $\mathrm{C}^{*}=10^{9} \mu \mathrm{g} \mathrm{m}^{-3} ; \mathrm{O}: \mathrm{C}=1.0$ ). Half of the products formed from the first-step fragmentation are assumed to be intermediates that can undergo further functionalization. As a result, a number of heavy fragments with similar $\mathrm{C}^{*}$ and $\mathrm{O}: \mathrm{C}$ as their precursors are produced. We invoke here the assumption that fragmentation leads to the formation of a one-carbon compound $\left(\mathrm{C}_{1}\right)$, which is formaldehyde, together with a co-product $\left(\mathrm{C}_{n-1}\right)$ that has the same collection of functional groups but one fewer carbon atom than the parent compound. The "random fragmentation" assumption in SOM acts to rapidly distribute mass over the entire $n_{\mathrm{C}}$ vs. $n_{\mathrm{O}}$ space. The initial products upon the first-step fragmentation in the 2-D VBS form a "hockey stick" shape, and the further oxidation of half of the initial products fills a wide area in the O : C vs. C* space (Jimenez et al., 2009; Donahue et al., 2012b). The "one carbon loss fragmentation" assumption leads to a somewhat slower progression of prediction of smaller fragments. These three different assumptions concerning the mechanism of fragmentation lead eventually to a similar final state characterized by a distribution of intermediates of a more volatile and oxygenated nature.

The role of fragmentation is evident in the chemical mechanisms shown in Fig. 2 (see also the Supplement). It is assumed that any of the hydrogen atoms on a secondary carbon is more or less equally vulnerable to $\mathrm{OH}$ attack, so instead of the exact structure of a specific molecule, we focus on the type and number of functional groups associated with a carbon backbone. Under low- $\mathrm{NO}_{\mathrm{x}}$ conditions, photolysis of $-\mathrm{OOH}$ groups and peroxy-peroxy reactions are the primary pathways leading to scission of the carbon skeleton. In the domain of low- $\mathrm{NO}_{\mathrm{x}} \mathrm{RO}_{2}+\mathrm{HO}_{2}$-dominated chemistry, the photolysis of an -OOH group generates an alkoxy radical, which decomposes to a carbonyl group (formaldehyde in the $\mathrm{C}_{1}+\mathrm{C}_{n-1}$ case) and an alkyl radical (R). Reaction of $\mathrm{R}$ with

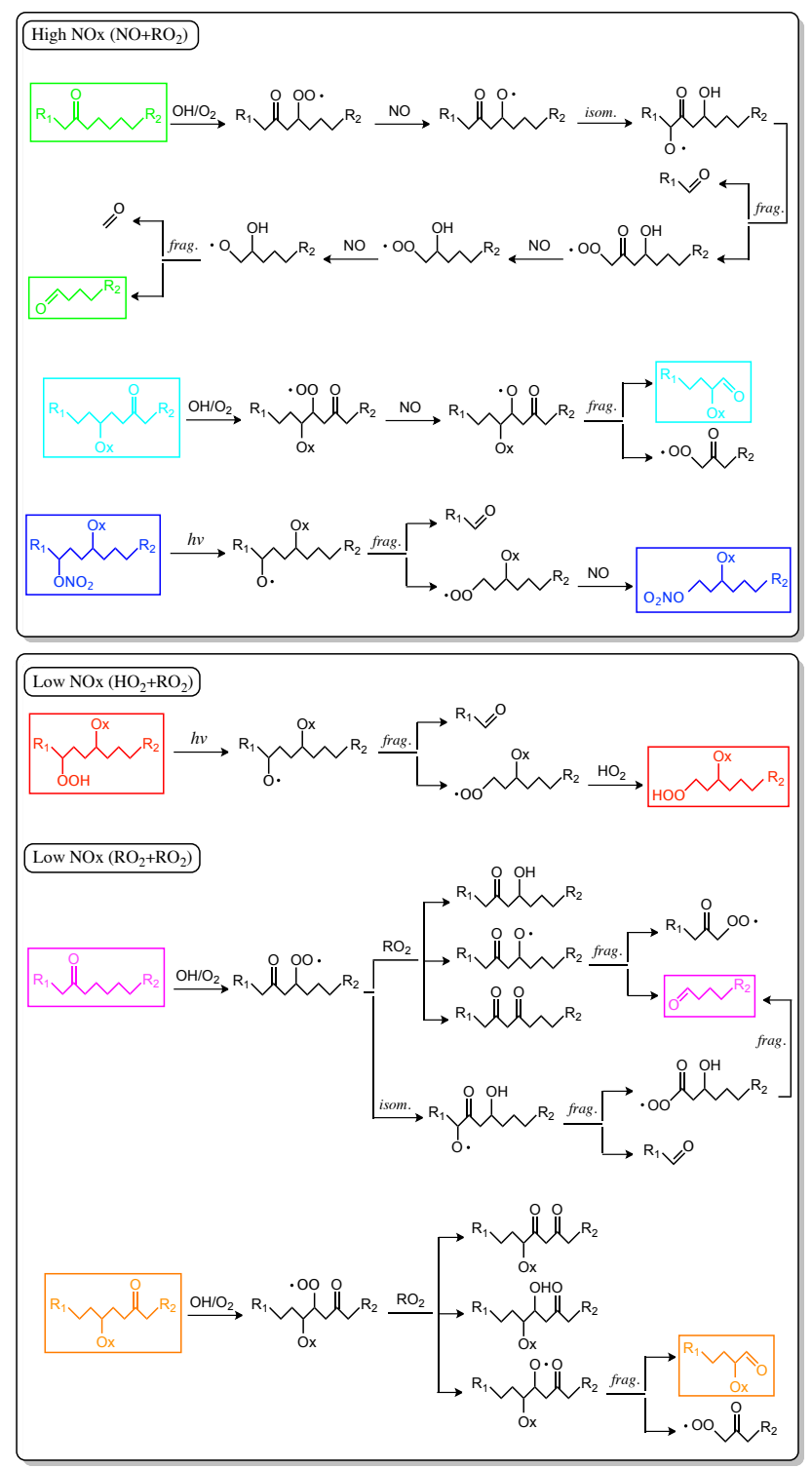

Fig. 2. Chemical mechanisms of alkane photooxidation underlying fragmentation processes.

$\mathrm{O}_{2}$ followed by reaction with $\mathrm{HO}_{2}$ regenerates the $-\mathrm{OOH}$ group; in $\mathrm{RO}_{2}+\mathrm{RO}_{2}$-dominated chemistry, the self-reaction of $\mathrm{RO}_{2}$ produces $-\mathrm{C}=\mathrm{O},-\mathrm{OH}$, and $\mathrm{RO}$. The decomposition of $\mathrm{RO}$ leads to $-\mathrm{C}=\mathrm{O}$ and $\mathrm{R}^{\prime}$. $\mathrm{R}^{\prime}$ reacts solely with $\mathrm{O}_{2}$ to form $\mathrm{R}^{\prime} \mathrm{O}_{2}$, which can initiate another $\mathrm{RO}_{2}+\mathrm{RO}_{2}$ or $\mathrm{RO}_{2}+\mathrm{HO}_{2}$ cycle. Under high- $\mathrm{NO}_{\mathrm{x}}$ conditions, $\mathrm{RO}$ is produced primarily from the photolysis of $-\mathrm{ONO}_{2}$ and $\mathrm{RO}_{2}+\mathrm{NO}$ reactions. RO decomposes to a carbonyl and an alkyl radical, which reacts with $\mathrm{O}_{2}$ to reform $\mathrm{RO}_{2}$. In the presence of a sufficiently high concentration of $\mathrm{NO}_{\mathrm{x}}, \mathrm{RO}_{2}$ will preferentially react with $\mathrm{NO}$ to form an alkoxy radical or a $-\mathrm{ONO}_{2}$ group again. We shall take $-\mathrm{ONO}_{2}$ as the only functional group formed upon the photolysis of $-\mathrm{ONO}_{2}$ because of its larger contribution to the decrease of vapor pressure than the fragments from the 
decomposition of an alkoxy radical. We also assume that the $\mathrm{OH}$ oxidation of an alcohol produces solely a carbonyl, so the presence of $-\mathrm{OH}$ will not affect the type of functional groups added upon fragmentation.

\subsection{Volatility estimation}

In fragmentation, if sufficient addition of functional groups takes place, each of the products may still have a sufficiently low vapor pressure to be considered as semivolatile. A critical feature of the model is a relationship between saturation mass concentration, $\mathrm{C}^{\circ}$, and the carbon number of a compound.

From the point of view of predicting physical properties, description in terms of functional groups tends to be more useful than in terms of elemental composition. But, by the same token, the experimentally measurable quantities tend to be best related to elemental composition. In order to reconcile these two approaches to molecular characterization in terms of SOA, it is useful to develop a correlation that relates vapor pressure of a pure component $\left(\right.$ or $\mathrm{C}^{\circ}$ ) to both functional groups and elemental amounts. The theory underlying this approach will be developed generally and subsequently applied in analysis of SOA formation from $\mathrm{C}_{12}$ alkanes.

Frequently used vapor pressure estimation methods are based on expressing the logarithm of vapor pressure as a linear combination of contributions from individual functional groups (Capouet and Müller, 2006; Pankow and Asher, 2008; Compernolle et al., 2011). On the other hand, an approximate linear relationship between $\mathrm{C}^{\circ}$ and elemental composition, as developed by Donahue et al. (2011), proves to be advantageous. Here we merge the "group contribution" and "element contribution" methods in order to relate the carbon number to a given saturation concentration of a compound $i$. The resulting expression is

$\log _{10} \frac{10^{6} p_{\mathrm{L}, i}^{0}\left(12 n_{\mathrm{C}}^{i}+h n_{\mathrm{C}}^{i}+16 n_{\mathrm{O}}^{i}+14 n_{N}^{i}\right)}{R T}$

$=\left(n_{\mathrm{C}}^{0}-n_{\mathrm{C}}^{i}\right) b_{\mathrm{C}}-n_{\mathrm{O}}^{i} b_{\mathrm{O}}-2 \frac{n_{\mathrm{C}}^{i} n_{\mathrm{O}}^{i}}{n_{\mathrm{C}}^{i}+n_{\mathrm{O}}^{i}} b_{\mathrm{CO}}-\sum n_{\text {func }}^{i} b_{\text {func }}$,

where $10^{6}$ is a unit conversion $\left(\mathrm{g} \mathrm{m}^{-3}\right.$ to $\left.\mu \mathrm{g} \mathrm{m}^{-3}\right), b_{\mathrm{C}}$ is the carbon-carbon interaction term, $b_{\mathrm{O}}$ is the oxygen-oxygen interaction term, $b_{\mathrm{CO}}$ is the carbon-oxygen interaction term, $b_{\text {func }}$ is the interaction term for different functional groups, $n_{\mathrm{C}}^{0}$ is the reference carbon number, $n_{\mathrm{C}}^{i}$ is the carbon number of compound $i, n_{\mathrm{O}}^{i}$ is the oxygen number of compound $i, n_{N}^{i}$ is the nitrogen number of compound $i, n_{\text {func }}^{i}$ is the number of different functional groups in compound $i$, and $h$ is the ratio of hydrogen number to carbon number of compound $i$. For the application to the alkane system to be presented, we have determined $n_{\mathrm{C}}^{0}, b_{\mathrm{C}}, b_{\mathrm{O}}, b_{\mathrm{CO}}$, and $b_{\text {func }}$ by fitting the above equation to the estimated vapor pressures of 1080 standard aliphatic compounds (see Supplement). After optimal fitting of Eq. (2) to the standard compound vapor pressures, the pre- dicted carbon number of a compound lies within the range of $10 \%$ uncertainty of its actual value.

To illustrate the application of the volatility-composition correlation, consider the mechanism of the $\mathrm{OH}$-oxidation of dodecane $\left(\mathrm{C}_{12} \mathrm{H}_{26}\right)$. For a typical ambient organic aerosol loading of several $\mu \mathrm{g} \mathrm{m}^{-3}$, let us assume for purpose of illustration that any compound with the saturation concentration less than $10^{3} \mu \mathrm{g} \mathrm{m}^{-3}$ can partition appreciably to the particle phase. The gray-shaded region in Fig. 3 defines the particlephase "boundary" for compounds having carbon numbers 12 and fewer. The lines define the carbon-number range and types of functional groups for oxidation products of dodecane under low- $\mathrm{NO}_{\mathrm{x}}$ conditions. The magenta line in the lower left-hand corner of the gray-shaded region, for example, indicates that a product with two - $\mathrm{OOH}$ groups and 12 to 7 carbon atoms has sufficiently low volatility to lie in the semivolatile region defined by $\mathrm{C}^{\circ}<10^{3} \mu \mathrm{g} \mathrm{m}^{-3}$. However, the cyan line in the upper right-hand corner of the "condensable region" indicates that a molecule with only one $-\mathrm{C}=\mathrm{O}$ group would need at least 17 carbon atoms to fall into the semivolatile region. This would necessitate some types of accretion reaction to occur given the $\mathrm{C}_{12}$ parent molecule. The trade-off between functionalization and fragmentation in the volatility of the products becomes evident in such a graphic representation.

\subsection{Gas-particle partitioning}

Gas-particle equilibrium partitioning of semivolatile products is assumed. From Raoult's law, $p_{i}=p_{\mathrm{L}, i}^{0} \gamma_{i} \chi_{i}$, where $p_{\mathrm{L}, i}^{0}(\operatorname{atm})$ is the vapor pressure of compound $i$ as a liquid, $\gamma_{i}$ is its activity coefficient on the mole fraction basis, and $\chi_{i}$ is the mole fraction of compound $i$ in the particle phase. When multiple condensed-phase compounds exists, the gasparticle partition coefficient $K_{\mathrm{p}, i}\left(\mathrm{~m}^{3} \mu \mathrm{mol}^{-1}\right)$ of compound $i$ is expressed as

$K_{\mathrm{p}, i}=\frac{S_{i}^{\mathrm{p}} / S_{T}^{\mathrm{p}}}{S_{i}^{\mathrm{g}}}=\frac{R T}{10^{6} p_{\mathrm{L}, i}^{0} \gamma_{i}}$,

where $S_{i}^{\mathrm{g}}$ is the molar concentration $\left(\mu \mathrm{mol} \mathrm{m}{ }^{-3}\right)$ of $i$ in the gas phase, $S_{i}^{\mathrm{p}}$ is the equilibrium molar concentration $\left(\mu \mathrm{mol} \mathrm{m}{ }^{-3}\right)$ of $i$ in the particle phase, and $S_{T}^{\mathrm{p}}$ is the molar concentration per unit volume of air $\left(\mu \mathrm{mol} \mathrm{m}^{-3}\right)$ of all the species in the absorbing organic particle phase. $R\left(\mathrm{~m}^{3}\right.$ atm $\mathrm{mol}^{-1} \mathrm{~K}^{-1}$ ) is the gas constant, and $T(\mathrm{~K})$ is temperature. The effective saturation concentration $\left(\mu \mathrm{g} \mathrm{m}^{-3}\right)$ is expressed as

$C_{i}^{*}=\frac{C_{i}^{\mathrm{g}} C_{T}^{\mathrm{p}}}{C_{i}^{\mathrm{p}}}=\frac{10^{6} p_{\mathrm{L}, i}^{0} \gamma_{i} \overline{M_{\mathrm{w}}}}{R T}$,

where $C_{i}^{\mathrm{g}}$ is the mass concentration $\left(\mu \mathrm{g} \mathrm{m}^{-3}\right)$ of $i$ in the gas phase, $C_{i}^{\mathrm{p}}$ is the equilibrium mass concentration $\left(\mu \mathrm{g} \mathrm{m}^{-3}\right)$ of $i$ in the particle phase, and $C_{T}^{\mathrm{p}}$ is the mass concentration per 


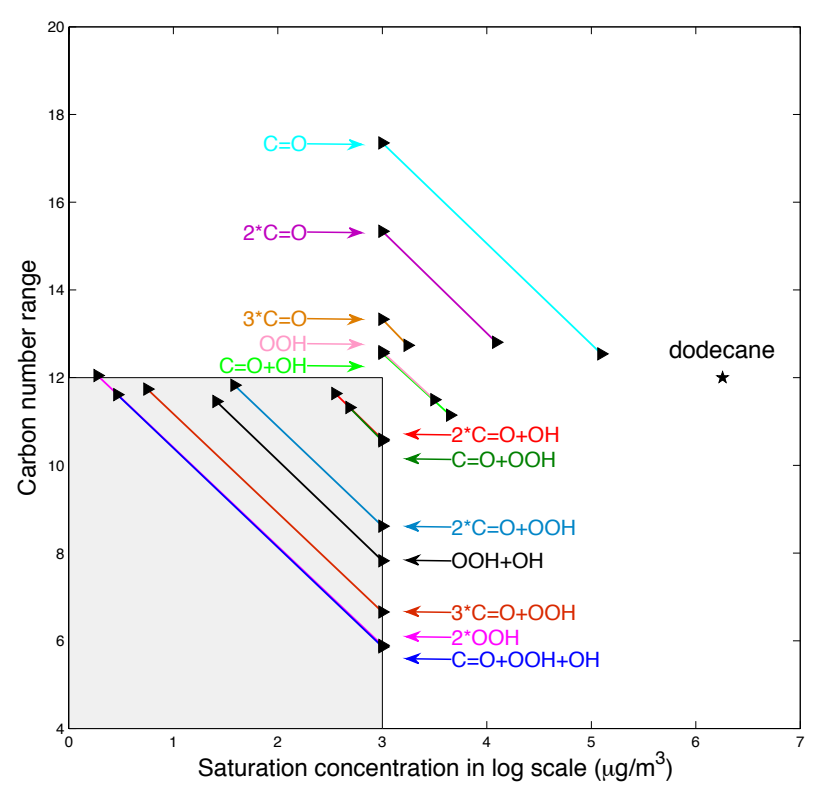

Fig. 3. Carbon-number range for products of $\mathrm{OH}$ oxidation of dodecane under low- $\mathrm{NO}_{\mathrm{x}}$ conditions. For illustration, the shaded region $\left(C^{\circ} \leq 1000 \mu \mathrm{g} \mathrm{m}^{-3}\right)$ is taken to represent the combination of carbon number and volatility for which a molecule can appreciably partition to the particle phase.

unit volume of air $\left(\mu \mathrm{g} \mathrm{m}^{-3}\right)$ of all the species in the absorbing organic particle phase. $\overline{M_{\mathrm{w}}}$ is the average molecular weight of the absorbing organic particle phase $\left(\mathrm{g} \mathrm{mol}^{-1}\right)$. Thus the fraction of $i$ in the particle phase, $\phi_{i}^{\mathrm{p}}$, is

$\phi_{i}^{\mathrm{p}}=\frac{1}{1+1 /\left(K_{\mathrm{p}, i} S_{\mathrm{T}}^{\mathrm{P}}\right)}=\frac{1}{1+C_{i}^{*} / C_{\mathrm{T}}^{\mathrm{P}}}$.

Note that the mole-fraction-based activity coefficient is assumed to be unity here. Nonideal interactions between organic and inorganic species in the aerosol phase influence the gas/particle partitioning of semivolatiles. Thermodynamic models show that the saturation concentration of species $i$ is usually overpredicted by assuming ideal condensed-phase behavior, and the extent of overprediction differs by functional groups and is affected by aerosol water content, as well as temperature and SOA loading (Zuend et al., 2010; Zuend and Seinfeld, 2012). Inclusion of particle-phase nonideality and phase separation is beyond the scope of the current study.

\subsection{Particle-phase accretion reactions}

Recent modeling studies have suggested that dehydration reactions in the particle phase can play an important role in determining the characteristics of the oxidation state (Chen et al., 2011; Cappa and Wilson, 2012), although the detailed mechanisms are uncertain. In the present FGOM framework, particle-phase accretion reactions (nonoxidative) are allowed to occur and assumed to generate essentially nonvolatile products. These reactions are treated as bimolecular, with a reaction rate constant $k_{\mathrm{a}}\left(\mathrm{m}^{3} \mathrm{~mol}^{-1} \mathrm{~s}^{-1}\right)$, which is a fitting parameter of the model. We assume that all of these nonvolatile compounds can be represented as a single generalized species, which is characterized by its time-dependent molar amount and the set $\left[\mathrm{C}_{x}, \mathrm{H}_{y}, \mathrm{O}_{z}\right]$, where the parameters $x, y$, and $z$ represent the numbers of carbon, hydrogen, and oxygen atoms characterizing the nonvolatile particle-phase composition. The parameters $x, y$, and $z$ are tunable parameters of the model. Note that certain limits are set for mathematically optimizing the $x$ value in order to conserve the carbon mass: the upper limit of the $x$ value is the sum of carbon numbers of two molecules with the parent carbon skeleton and the $x$ value cannot be lower than the sum of carbon numbers of two molecules that have the lowest carbon numbers in the category of semivolatile compounds defined by Eq. (2). The oxygen and hydrogen masses are not conserved in the specification of $y$ and $z$, in view of the formation of water molecules during the oligomerization processes.

\subsection{Summary of the functional group oxidation model (FGOM)}

The structure of the FGOM is summarized as follows. The type and number of functional groups added to the parent molecule over multi-generation oxidation are specified from consideration of an explicit chemical mechanism, such as GECKO-A or MCM (MCM is employed in the current FGOM model structure). As functionalization proceeds, a spectrum of products that are characterized by various combinations of functional groups together with the parent carbon backbone is generated. The accompanying fragmentation leads to products with the same functional groups as the parent product but with fewer $\mathrm{C}$ atoms. The automatically generated fragments are subject to the same oxidation mechanisms as the parent products. Vapor pressures of oxidation products are estimated by the vapor pressure prediction model "EVAPORATION" (Compernolle et al. 2011). Products formed partition to the particle phase, where they may either be oxidized following the same gas-phase mechanism or undergo accretion reactions. The model contains six tunable parameters: $r_{\mathrm{p}}$, the ratio of the particle-phase oxidative reaction rate constant to that in the gas phase; $f_{v}$, the parameter characterizing the probability of fragmentation; $k_{\mathrm{a}}$, the accretion reaction rate constant in the particle phase; and a matrix $\left[\mathrm{C}_{x}, \mathrm{H}_{y}, \mathrm{O}_{z}\right]$ of the carbon, hydrogen, and oxygen numbers of the nonvolatile products. These six parameters are incorporated in a set of differential equations governing the kinetics of all the species in the mechanism. The differential equations are solved numerically, with instantaneous equilibrium partitioning calculated at each time step. The number of differential equations for a certain VOC system depends on the chemical nature of the parent hydrocarbon (e.g., structure, volatility, etc.) and the complexity of the functionalization mechanism. Evolution of these six parameters describes the gas- and particle-phase 
Table 1. Secondary organic aerosol yields and initial experimental conditions for $\mathrm{OH}$ oxidation of $\mathrm{C}_{12}$ alkanes.

\begin{tabular}{|c|c|c|c|c|c|c|c|c|}
\hline & Compound & $\mathrm{OH}$ source & $\begin{array}{l}\text { Seed Conc. }\left(\mathrm{NH}_{4}\right)_{2} \mathrm{SO}_{4} \\
\mu \mathrm{m}^{3} \mathrm{~cm}^{-3}\end{array}$ & $\begin{array}{l}\mathrm{HC}_{0} \\
(\mathrm{ppb})\end{array}$ & $\begin{array}{l}\mathrm{NO}_{0} \\
(\mathrm{ppb})\end{array}$ & $\begin{array}{l}\mathrm{NO}_{20} \\
(\mathrm{ppb})\end{array}$ & $\begin{array}{c}\mathrm{OH}_{0} \\
\left(\text { molec } \mathrm{cm}^{-3}\right)\end{array}$ & $\begin{array}{l}\text { Yield }^{*} \\
(\%)\end{array}$ \\
\hline \multirow[t]{4}{*}{ High $\mathrm{NO}_{\mathrm{x}}$} & dodecane & HONO & 8.6 & 32.2 & 343 & 429 & $4.20 \times 10^{7}$ & 5.8 \\
\hline & methylundecane & HONO & 15.4 & 72.4 & 366 & 424 & $3.90 \times 10^{7}$ & 5.6 \\
\hline & hexylcyclohexane & HONO & 12.1 & 22.1 & 320 & 399 & $3.19 \times 10^{7}$ & 17.7 \\
\hline & cyclododecane & HONO & 7.5 & 13.8 & 289 & 444 & $2.40 \times 10^{7}$ & 41.3 \\
\hline \multirow[t]{4}{*}{ Low $\mathrm{NO}_{\mathrm{x}}$} & dodecane & $\mathrm{H}_{2} \mathrm{O}_{2}$ & 10.8 & 34.0 & $<2$ & $<4$ & $2.59 \times 10^{6}$ & 16.0 \\
\hline & methylundecane & $\mathrm{H}_{2} \mathrm{O}_{2}$ & 15.2 & 28.0 & $<2$ & $<4$ & $2.29 \times 10^{6}$ & 15.1 \\
\hline & hexylcyclohexane & $\mathrm{H}_{2} \mathrm{O}_{2}$ & 10.5 & 15.6 & $<2$ & $<4$ & $2.81 \times 10^{6}$ & 34.8 \\
\hline & cyclododecane & $\mathrm{H}_{2} \mathrm{O}_{2}$ & 13.8 & 10.4 & $<2$ & $<4$ & $3.04 \times 10^{6}$ & 47.3 \\
\hline
\end{tabular}

* The values determined here are final yields - i.e., the mass of aerosol formed per mass of alkane reacted after $3 \mathrm{~h}$ and $35 \mathrm{~h}$, respectively, in high- vs. low-NO $\mathrm{x}$ experiments.

chemistry, together with the instantaneous equilibrium partitioning process. Their values are determined by optimal fitting of the model simulations of organic mass growth and elemental compositions with laboratory chamber data (organic aerosol mass, $\mathrm{O}: \mathrm{C}$, and $\mathrm{H}: \mathrm{C}$ ). These three properties are equally weighted to constitute the overall optimization objective function. The Levenberg-Marquardt method implemented in MATLAB's "System Identification Toolbox" (MathWorks, 2002) is used for the nonlinear minimization. The essential feature of the FGOM model that distinguishes it from explicit chemical models is the simplified treatment of fragmentation processes: the fragmentation operator (in the form of $f_{v}$ ) is applied to determine the probability that a given stable molecule will fragment, instead of accounting for the detailed free-radical chemistry. Owing to the consideration of carbon-number-conserved oxidation reactions based on the explicit chemistry, the FGOM model differs from the 2-D VBS or SOM models in terms of the treatment of particle-phase oxidative and nonoxidative reactions through the parameters $r_{\mathrm{p}}, k_{\mathrm{a}}$, and $\left[\mathrm{C}_{x}, \mathrm{H}_{y}, \mathrm{O}_{z}\right]$.

\subsection{Application to SOA formation for $\mathrm{C}_{12}$ alkanes}

The FGOM is applied to predict SOA formation from the $\mathrm{OH}$-initiated oxidation of four $\mathrm{C}_{12}$ alkanes (dodecane, methylundecane, hexylcyclohexane, and cyclododecane) under both high- and low- $\mathrm{NO}_{\mathrm{x}}$ conditions. Experiments were carried out in the dual $28 \mathrm{~m}^{3}$ Teflon reactors in the Caltech environmental chamber. Detailed descriptions of experimental protocols can be found elsewhere (Yee et al., 2012; Craven et al., 2012). Experimental conditions are summarized in Table 1. Different OH-radical sources were employed to achieve high- and low- $\mathrm{NO}_{\mathrm{x}}$ levels. For low- $\mathrm{NO}_{\mathrm{x}}$ conditions, experiments were designed to capture $36 \mathrm{~h}$ of total photooxidation during which the $\mathrm{OH}$ concentration produced from the photolysis of $\mathrm{H}_{2} \mathrm{O}_{2}$ remains essentially constant. Under high- $\mathrm{NO}_{\mathrm{x}}$ conditions, the $\mathrm{OH}$ source is HONO. The photolysis rate of $\mathrm{HONO}$ is about an order of magnitude higher than that of $\mathrm{H}_{2} \mathrm{O}_{2}$, leading to a depletion of $\mathrm{OH}$ within $\sim 3 \mathrm{~h}$. For both cases, the time-dependent $\mathrm{OH}$ concentration can be obtained by optimal fitting of the predicted parent hydrocarbon decay with its measured temporal profile. Three measured SOA properties - i.e., organic mass growth, O : C ratio, and $\mathrm{H}: \mathrm{C}$ ratio - are employed to constrain the performance of FGOM. Protocols of experimental data processing can be found in the Supplement. Two simulations were run for each $\mathrm{C}_{12}$ alkane system: sim.1, the full fitting of the six empirical parameters in the FGOM to the chamber data, and sim.2, fitting two parameters " $f_{v}$ " and " $r_{\mathrm{p}}$ " to the organic mass concentration. The best-fit parameters obtained for the four $\mathrm{C}_{12}$ alkanes for both high- $\mathrm{NO}_{\mathrm{x}}$ and low- $\mathrm{NO}_{\mathrm{x}}$ conditions are given in Table 2.

Questions associated with the application of FGOM are as follows: (1) How well does the model reproduce the measured SOA properties? (2) Are all six parameters equally influential in terms of representing SOA formation and evolution? and (3) How well do these mathematically best-fit parameters express the actual chemistry thought to be occurring in the system? Some general findings include the following: (1) $f_{v}$ values are generally lower under high- $\mathrm{NO}_{\mathrm{x}}$ conditions, indicating more intense fragmentation. The abundance of $\mathrm{RO}$ is the most important determinant of the degree of fragmentation. In the presence of $\mathrm{NO}_{\mathrm{x}}$, the primary fate of $\mathrm{RO}_{2}$ is reaction with $\mathrm{NO}$, producing $\mathrm{RO}$. All of the low$\mathrm{NO}_{\mathrm{x}}$ experiments fall into the $\mathrm{HO}_{2}+\mathrm{RO}_{2}$ dominant regimes as $>95 \% \mathrm{RO}_{2}$ will react with $\mathrm{HO}_{2}$. Although the photolysis of the $-\mathrm{OOH}$ group formed from $\mathrm{HO}_{2}+\mathrm{RO}_{2}$ reaction leads to the formation of $\mathrm{RO}$, the yield of $\mathrm{RO}$ via this path is still an order of magnitude lower than under high- $\mathrm{NO}_{\mathrm{x}}$ conditions. In addition, $f_{v}$ values for cycloalkanes are higher than those for straight-chain alkanes, which is consistent with the mechanism of the decomposition of RO in a nonaromatic ring. (2) Optimal $r_{\mathrm{p}}$ values for the eight alkane systems range from $10^{-3}$ to $10^{-1}$, that is, the particle-phase oxidation reaction rates are predicted to be at least one order of magnitude slower than those in the gas phase. The role of particlephase oxidative reactions in the SOA formation from $\mathrm{C}_{12}$ alkanes is therefore not strongly influential during the initial period 
Table 2. Best-fit parameters for $\mathrm{OH}$-initiated oxidation of $\mathrm{C}_{12}$ alkanes. $r_{\mathrm{p}}$ is the ratio of the particle-phase oxidative reaction rate constant to that in the gas phase. $f_{v}$ is the parameter characterizing the probability of fragmentation. $k_{\mathrm{a}}$ is the accretion reaction rate constant in the particle phase. The matrix $\left[\mathrm{C}_{x}, \mathrm{H}_{y}, \mathrm{O}_{z}\right]$ represents the carbon, hydrogen, and oxygen numbers of the nonvolatile products. For each alkane, the first entry is the full set nonlinear minimization (sim.1) and the second entry is the fit of only $f_{v}$ and $r_{\mathrm{p}}$ to the total organic mass concentration $(\operatorname{sim} .2)$.

\begin{tabular}{|c|c|c|c|c|c|}
\hline & & $f_{v}^{\mathrm{a}}$ & $r_{\mathrm{p}}^{\mathrm{b}}$ & $\left(\mathrm{m}^{3} \mathrm{~mol}_{\mathrm{a}}^{\mathrm{c}} \mathrm{s}^{-1}\right)$ & {$\left[\begin{array}{lll}\mathrm{C}_{x} & \mathrm{H}_{y} & \mathrm{O}_{z}\end{array}\right]^{\mathrm{d}}$} \\
\hline \multirow[t]{8}{*}{ High $\mathrm{NO}_{\mathrm{x}}$} & dodecane & 0.57 & $1.12 \times 10^{-2}$ & $9.99 \times 10^{3}$ & {$\left[\begin{array}{llll}21.21 & 21.83 & 3.23\end{array}\right]$} \\
\hline & & 0.65 & $9.90 \times 10^{-3}$ & - & - \\
\hline & methylundecane & 0.66 & $1.07 \times 10^{-2}$ & $1.02 \times 10^{4}$ & {$\left[\begin{array}{lll}24.00 & 30.21 & 1.16\end{array}\right]$} \\
\hline & & 0.81 & $1.00 \times 10^{-2}$ & - & - \\
\hline & hexylcyclohexane & 0.76 & $1.35 \times 10^{-1}$ & $5.28 \times 10^{4}$ & {$\left[\begin{array}{llll}22.12 & 31.23 & 5.84\end{array}\right]$} \\
\hline & & 1.10 & $1.00 \times 10^{-3}$ & - & - \\
\hline & cyclododecane & 0.89 & $1.00 \times 10^{-3}$ & $1.05 \times 10^{4}$ & {$\left[\begin{array}{llll}23.49 & 27.42 & 3.30\end{array}\right]$} \\
\hline & & 1.42 & $1.00 \times 10^{-3}$ & - & - \\
\hline \multirow[t]{8}{*}{ Low $\mathrm{NO}_{\mathrm{x}}$} & dodecane & 0.61 & $1.00 \times 10^{-3}$ & $5.95 \times 10^{3}$ & {$\left[\begin{array}{lllll}24.00 & 39.38 & 5.59\end{array}\right]$} \\
\hline & & 0.77 & $1.00 \times 10^{-3}$ & - & - \\
\hline & methylundecane & 0.67 & $1.00 \times 10^{-3}$ & $5.70 \times 10^{3}$ & {$\left[\begin{array}{llll}24.00 & 37.78 & 5.32\end{array}\right]$} \\
\hline & & 0.91 & $1.00 \times 10^{-3}$ & - & - \\
\hline & hexylcyclohexane & 0.82 & $8.99 \times 10^{-2}$ & $6.01 \times 10^{3}$ & {$\left[\begin{array}{llll}18.03 & 26.44 & 6.00\end{array}\right]$} \\
\hline & & 1.00 & $1.00 \times 10^{-3}$ & - & - \\
\hline & cyclododecane & 0.89 & $1.00 \times 10^{-3}$ & $1.86 \times 10^{3}$ & {$\left[\begin{array}{llll}23.36 & 31.42 & 3.29\end{array}\right]$} \\
\hline & & 2.00 & $1.00 \times 10^{-3}$ & - & - \\
\hline
\end{tabular}

\footnotetext{
a The probability of fragmentation $\left(P_{\mathrm{f}}\right)$ should be within the range of 0 to 1 .

b The upper and lower limits for $r_{\mathrm{p}}$ are set to be 1 and $10^{-3}$, respectively.

c No upper limit is applied to $k_{\mathrm{a}}$.

$\mathrm{d}$ The upper limit of $x$ value should be 24 for $\mathrm{C}_{12}$ alkanes studied here and the $x$ value cannot be lower than the sum of two molecules with the lowest carbon numbers in the category of semivolatile compounds defined by Eq. (2); the upper limit of $y$ value should be the hydrogen number of the $C_{24}$ alkane; and $z$ value ranges from 0 to the sum of two molecules that have the largest oxygen number generated from the functionalization channel.
}

of time. However, for species with very low vapor pressure (e.g., $1 \times 10^{-11}$ atm), $99.8 \%$ of which will end up being in the particle phase at a moderate organic aerosol loading, e.g., $40 \mu \mathrm{g} \mathrm{m}^{-3}$, particle-phase oxidative reactions are as influential as those in the gas phase even if $r_{\mathrm{p}}$ is of the order of $10^{-3}$. Most semivolatile products generated from the functionalization channel of the FGOM have vapor pressure higher than $10^{-10} \mathrm{~atm}$, and as a result, their particle-phase oxidative reactions are predicted to be a minor path when $r_{\mathrm{p}}$ is less than $10^{-1}$, a prediction that is consistent with field and experimental evidence (Murphy, et al., 2007; DeCarlo et al., 2008; George et al., 2008; Lambe et al., 2009). (3) Optimal $k_{\mathrm{a}}$ values for the eight alkane systems range from $10^{3}$ to $10^{4} \mathrm{~m}^{3}$ $\mathrm{mol}^{-1} \mathrm{~s}^{-1}$, indicating that accretion reactions occurring in the particle phase are predicted to play an important role in SOA properties, given the high local concentrations of the species in the condensed phase. Take the low- $\mathrm{NO}_{\mathrm{x}}$ photooxidation of dodecane as an example; the predicted nonvolatile species eventually account for $\sim 30 \%$ of the total organic aerosol; see Fig. 9. (4) Optimal values of the matrix $\left[\mathrm{C}_{x}, \mathrm{H}_{y}\right.$, $\mathrm{O}_{z}$ ] for the eight systems indicate a highly dehydrated nature of the nonvolatile species. Since the explicit particle-phase reaction mechanisms in these systems are not yet clear, one cannot assess unambiguously the effect of particle-phase reactions on the SOA aging. We will return to the importance of the five particle-phase parameters in Sect. 3.3.

\subsection{Organic aerosol growth}

The predicted (FGOM) temporal profiles of organic aerosol mass $\left(\mathrm{C}_{\mathrm{OA}}\right)$, together with the wall-loss-corrected chamber data, for the four $\mathrm{C}_{12}$ alkane systems based on the optimal fit parameters in Table 2 are shown in Fig. 4. SOA yields under high- $\mathrm{NO}_{\mathrm{x}}$ conditions are lower than those under low$\mathrm{NO}_{\mathrm{x}}$ conditions because of both the shorter $\mathrm{OH}$-radical exposure time and the more intense fragmentation in the presence of $\mathrm{NO}_{\mathrm{x}}$. The SOA growth curves under various $\mathrm{NO}_{\mathrm{x}}$ levels show different patterns. Particles start to grow immediately after the initiation of photochemistry under high- $\mathrm{NO}_{\mathrm{x}}$ conditions, whereas a short lag occurs before organic aerosol mass accumulates under low $\mathrm{NO}_{\mathrm{x}}$. The initial $\mathrm{OH}$ concentration under high- $\mathrm{NO}_{\mathrm{x}}$ conditions is an order of magnitude higher than that in low $\mathrm{NO}_{\mathrm{x}}$, which substantially accelerates the progression of multi-generation oxidation and consequently the early stage formation of low-volatility compounds. In addition, the $\mathrm{RO}$ chemistry occurring under high- $\mathrm{NO}_{\mathrm{x}}$ conditions 


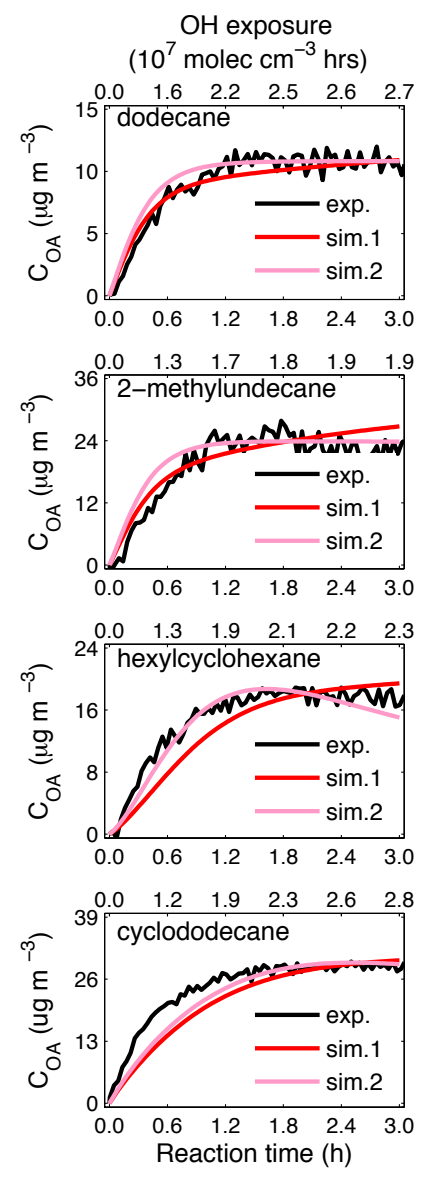

High-NOx
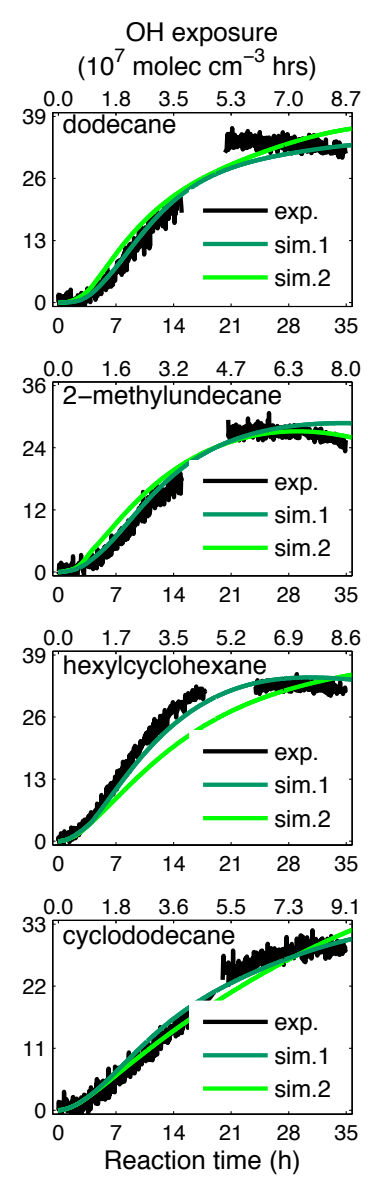

Low-NOx

Fig. 4. Simulated (colors) and observed (black) time-dependent organic aerosol growth from the photooxidation of four $\mathrm{C}_{12}$ alkanes under high- (red) and low- (green) $\mathrm{NO}_{\mathrm{x}}$ conditions. Note that "sim. 1 " represents the full fitting of the six empirical parameters $\left(r_{\mathrm{p}}\right.$ is the ratio of the particle-phase oxidative reaction rate constant to that in the gas phase. $f_{v}$ is the parameter characterizing the probability of fragmentation; $k_{\mathrm{a}}$ is the accretion reaction rate constant in the particle phase; and the matrix $\left[\mathrm{C}_{x}, \mathrm{H}_{y}, \mathrm{O}_{z}\right]$ represents the carbon, hydrogen, and oxygen numbers of the nonvolatile products) in the FGOM to the chamber data and "sim.2" refers to fitting by only two parameters, $r_{\mathrm{p}}$ and $f_{v}$, to the organic mass concentration.

leads to products spanning a wider range of volatilities after only one generation of oxidation.

The level-off of $\mathrm{C}_{\mathrm{OA}}$ at the end of the experiments is generally not captured for all the eight alkane systems. The leveloff could have resulted from re-evaporation of particles under low- $\mathrm{NO}_{\mathrm{x}}$ conditions and the cessation of $\mathrm{OH}$ production under high- $\mathrm{NO}_{\mathrm{x}}$ conditions. Reproduction of $\mathrm{C}_{\mathrm{OA}}$ requires accurate representation of the trade-off between the fragmentation of semivolatile products and the formation of particlephase nonvolatile products, which results in an accumulation of total particle organic mass. The $\mathrm{C}_{\mathrm{OA}}$ growth curves for cyclododecane under high- $\mathrm{NO}_{\mathrm{x}}$ conditions are not as closely

simulated as for the other alkanes. For cyclododecane, particles are observed to grow fairly rapidly after the inception of photooxidation.

An essential feature of the FGOM is the prediction of the emergence of a spectrum of functional groups as the oxidation proceeds. For the alkanes investigated here, the $\mathrm{C}_{12}$ backbone is not predicted to break until 3-5 functional groups have been added to the parent chain. As a result, 7-8 generations of oxidation are predicted to occur until the last remaining $\mathrm{C}_{12}$ backbone is fragmented. In the FGOM model, every possible oxidation step leading to functionalization is implicitly considered in the generalized mechanism. The extent to which aging proceeds then depends on the availability of oxidants. Figure 5 shows the predicted contribution of different generations of products to the total organic aerosol mass for the eight alkane systems. The $\mathrm{OH}$ exposure time under low- $\mathrm{NO}_{\mathrm{x}}$ conditions is, on average, $\sim 3$ times higher than that under high- $\mathrm{NO}_{\mathrm{x}}$ conditions. As a result, the 2nd- and 3rd-generation products are dominant components at high $\mathrm{NO}_{\mathrm{x}}$, whereas 4th- and later generation products account for over $50 \%$ of the total aerosol mass at the end of the low- $\mathrm{NO}_{\mathrm{x}}$ experiments. The temporal distribution of multi-generational products reflects different chemical mechanisms governing the photochemistry under high- vs. low- $\mathrm{NO}_{\mathrm{x}}$ conditions. Due to the importance of $\mathrm{RO}$ chemistry in the presence of $\mathrm{NO}_{\mathrm{x}}$, a spectrum of products spanning a large range of volatility and oxidation states are formed upon the $\mathrm{OH}$ initiated photooxidation. Under low- $\mathrm{NO}_{\mathrm{x}}$ conditions, products containing the $-\mathrm{OOH}$ group dominate the particle phase due to their low volatilities, although most of these are consumed rapidly in the gas phase. In general, the extent of agreement between predicted and observed chamber data for the initial SOA growth depends on the matrix of functional groups generated as oxidation proceeds. For example, GECKO-A generates $2 \%$ trifunctional species in the 1st-generation products from $\mathrm{C}_{16}$ alkanes (Aumont et al., 2012), products that are not included in MCM 3.1. Because of their low volatility, a small amount of trifunctional species could contribute substantially to the particle mass.

\subsection{Elemental aerosol composition}

Wall-loss-corrected chamber SOA yield data (i.e., yields computed accounting for particle deposition on chamber walls) have been used as a standard for the fitting of empirical models, such as the 2-product model and the 1D VBS. The subtleties of using AMS-derived atomic ratios $(\mathrm{O}: \mathrm{C}$ and $\mathrm{H}: \mathrm{C})$ as well lie in the uncertainties in the AMS elemental analysis, which arise from variations in the ionization and fragmentation of compounds in the AMS and uncertainties in analysis of high-resolution mass spectra (Chhabra et al., 2010). The ionization efficiency for different molecules varies depending on the identity and structure of molecules being ionized. Uncorrected $\mathrm{O}: \mathrm{C}$ and $\mathrm{H}: \mathrm{C}$ tend to be biased low due to the neutral losses of oxygen- 


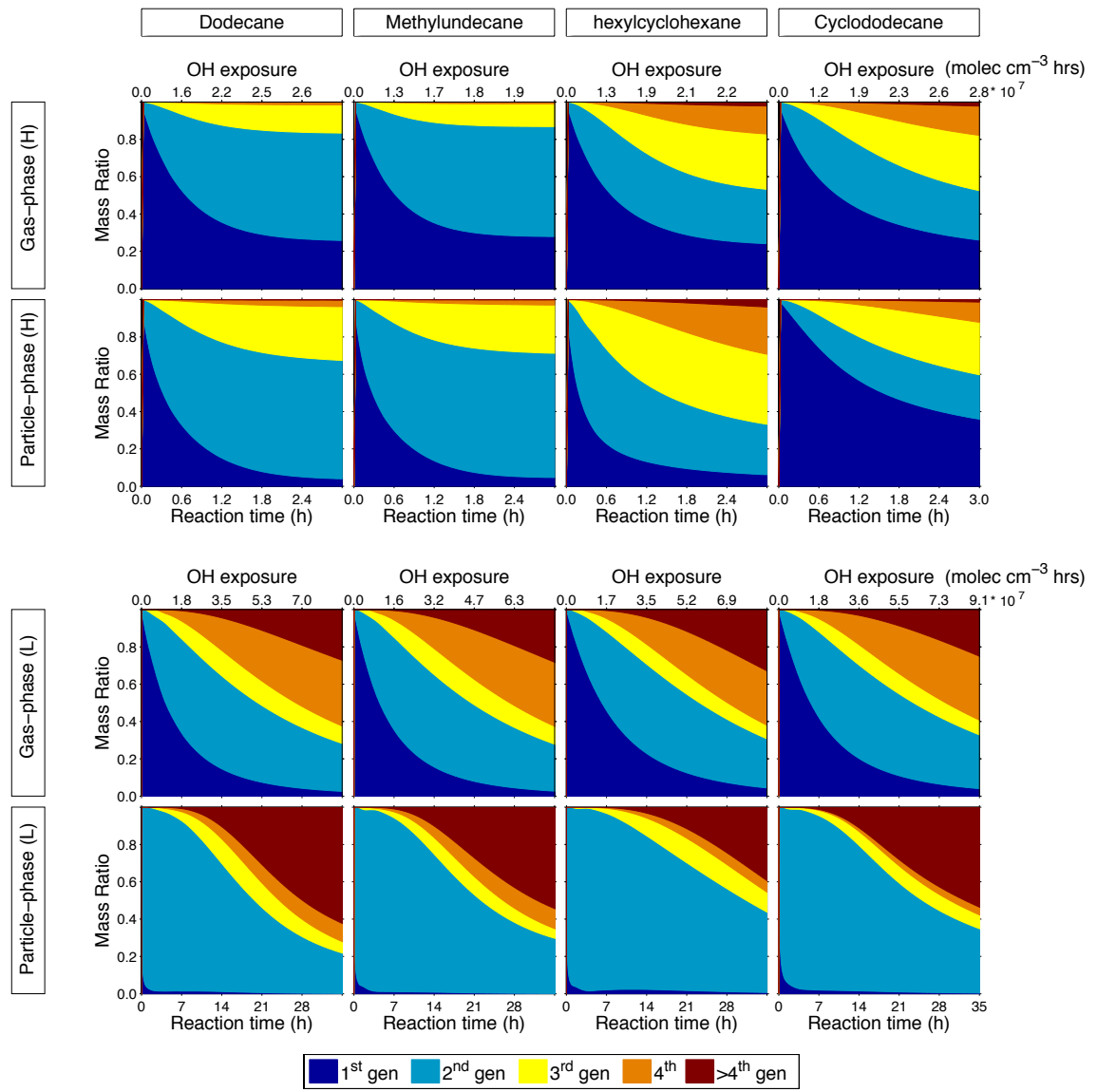

Fig. 5. Time evolution of predicted gas- and particle-phase multi-generational products from $\mathrm{OH}$ oxidation of $\mathrm{C}_{12}$ alkanes under high- and low- $\mathrm{NO}_{\mathrm{x}}$ conditions (upper and lower panel, respectively).

and hydrogen-containing fragments, such as $\mathrm{H}_{2} \mathrm{O}, \mathrm{CO}_{2}, \mathrm{H}$, and $\mathrm{H}_{2}$. As a result, the raw measurement of elemental composition requires calibration factors derived from the standard analysis. In this study, the calibration factors applied to AMS measured $\mathrm{O}: \mathrm{C}$ and $\mathrm{H}: \mathrm{C}$ are 0.75 and 0.91 , respectively (Aiken et al., 2007, 2008). The uncertainties in O:C and $\mathrm{H}: \mathrm{C}$ ratios, defined as the average absolute value of the relative error of each data point from any standard analyzed with respect to the regression line, were measured to be $31 \%$ and $10 \%$, respectively (Aiken et al., 2008). In this study, we use these two values as the upper boundaries, marked as gray error bars in Figs. 6 and 7, considering the fact that organic aerosol is a mixture of thousands of pure compounds. A transient set of data points for a particular experiment serves as the basis for carrying out the fitting processes (here these comprise the AMS-derived $\mathrm{O}: \mathrm{C}$ and $\mathrm{H}: \mathrm{C}$ ). When comparing the optimal model fit with experimentally measured $\mathrm{O}: \mathrm{C}$ and $\mathrm{H}: \mathrm{C}$, the model output can be considered to reasonably match the experimental ratios as long as the prediction falls within the gray region.
Figure 6 shows the measured and simulated particle average $\mathrm{O}: \mathrm{C}$ ratios for the $\mathrm{OH}$ oxidation of dodecane, methylundecane, hexylcyclohexane, and cyclododecane. The experiments simulated here result in moderate levels of oxidation - i.e., $\mathrm{O}: \mathrm{C} \sim 0.3$ in the semivolatile oxygenated organic aerosol (SV-OOA) range (Ng et al., 2010, 2011). Note that for a typical experiment, we first sample the purified chamber air with a filter in line to measure the organic loadings by AMS for three replicates and obtain the average organic loading value as the AMS detection limit. If the organic aerosol mass growth in the chamber is below the detection limit, that AMS measurement is deemed unreliable. For low- $\mathrm{NO}_{\mathrm{x}}$ experiments, particle growth usually starts after about $4 \mathrm{~h}$ of reaction. During this initial period, the noise-to-signal ratio is high and data are deemed not reliable. The measured $\mathrm{O}: \mathrm{C}$ ratio begins at zero and then rapidly increases as the early low volatility compounds condense. As $\mathrm{C}_{\mathrm{OA}}$ increases, species with higher volatilities are capable of partitioning to the particle phase, causing $\mathrm{O}: \mathrm{C}$ to decrease. The $\mathrm{O}: \mathrm{C}$ trend thus represents a competition between the decrease due to the partitioning of higher volatility compounds with fewer O-atoms 

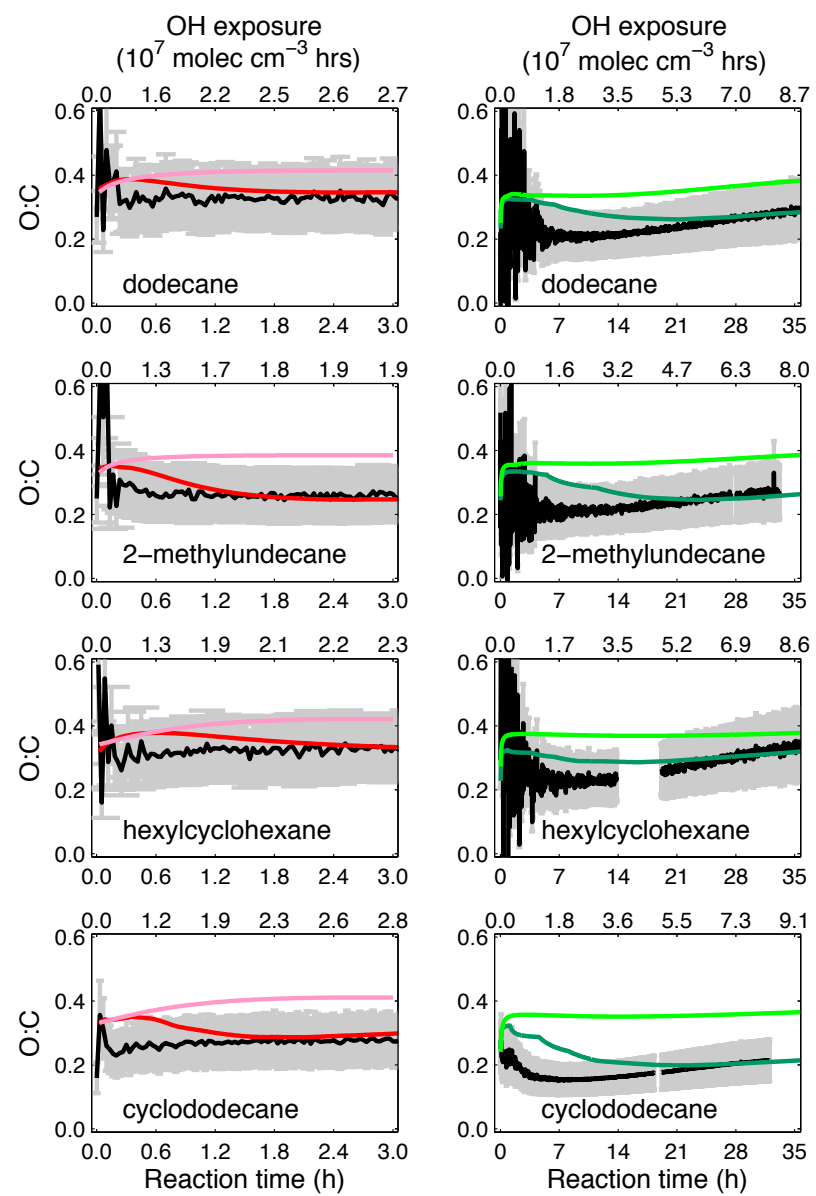

High-NOx

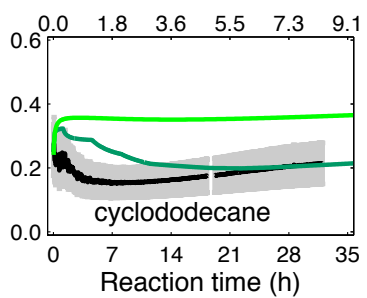

Low-NOx

Fig. 6. Simulated (colors) and observed (black) temporal profiles of particulate $\mathrm{O}: \mathrm{C}$ ratio from the photooxidation of $\mathrm{C}_{12}$ alkanes under high- (red) and low- (green) $\mathrm{NO}_{\mathrm{x}}$ conditions. Dark colors denote "sim.1" and light colors denote "sim.2".

and the increase that results from partitioning of more oxygenated compounds as multiple generations unfold. Owing to less reliable data at the onset of AMS sampling, we consider the data points in the middle of the span - i.e., O : C $\sim 0.2-0.3$ - as the "standard" for the comparison with simulations from "sim.1". Predictions under high- $\mathrm{NO}_{\mathrm{x}}$ conditions are generally consistent with the measured values. No increase in $\mathrm{O}: \mathrm{C}$ ratio is observed because of the experimental depletion of $\mathrm{OH}$ radicals after $\sim 3 \mathrm{~h}$ reaction. In general, the $\mathrm{O}: \mathrm{C}$ ratios under high- $\mathrm{NO}_{\mathrm{x}}$ conditions are predicted to be higher than under low- $\mathrm{NO}_{\mathrm{x}}$ conditions because the formation of $-\mathrm{ONO}_{2}$ groups introduces more oxygen to the particles than the $-\mathrm{OOH}$ group. The agreement between predicted and measured $\mathrm{O}: \mathrm{C}$ ratios under low- $\mathrm{NO}_{\mathrm{x}}$ conditions is less satisfactory. Simulations with solely gas-phase chemistry can reproduce the $\mathrm{O}: \mathrm{C}$ trend, which is in agreement with our current understanding of SOA formation and aging driven by gas-phase photooxidation of semivolatiles, but

fail to match the measured $\mathrm{O}: \mathrm{C}$ values. When an oligomer formation channel is incorporated, the model output is capable of matching the measured $\mathrm{O}: \mathrm{C}$ ratio eventually, but exhibits a different temporal profile pattern: while the observed $\mathrm{O}: \mathrm{C}$ is rising, the modeled $\mathrm{O}: \mathrm{C}$ is falling within $\sim 20 \mathrm{~h}$ reaction. This results from the difference between the theoretical alkane SOA makeup and the chemical properties of actual alkane SOA measured by AMS in the chamber. Consider the dodecane low- $\mathrm{NO}_{\mathrm{x}}$ case (Fig. 6) as an example: the starting point of the $\mathrm{O}: \mathrm{C}$ ratio measured by the AMS is $\sim 0.2$, which means that a typical compound that is present in the particle phase with a $\mathrm{C}_{12}$ carbon backbone has, on average, 2.4 oxygen atoms. However, based on the vapor pressure prediction models (SIMPOL.1 or EVAPORATION), such a "compound" cannot have sufficiently low vapor pressure to be dominant in the particle phase at the beginning of the photochemistry. Overall, the inconsistency between modeled and measured $\mathrm{O}: \mathrm{C}$ ratios reflects a discrepancy between the fitting of a semiexplicit model to a presumed elemental composition standard, and the current understanding of gas-phase photochemistry leading to the SOA formation.

For each of the four alkane systems studied here, gasphase chemistry alone is not able to match the chamber measured $\mathrm{O}: \mathrm{C}$ ratio, assuming it is perfectly correct. Oligomer formation, on the other hand, provides a pathway that could possibly shift the modeled $\mathrm{O}: \mathrm{C}$ ratio close to the observations. As noted, the FGOM does not reproduce the observed $\mathrm{O}: \mathrm{C}$ data for the cyclododecane case. The initial organic mass growth observed from the $\mathrm{OH}$ oxidation of cyclododecane is consistent with rapid functionalization. Based on gasphase chemical mechanisms, cycloalkanes should become more oxygenated as the breakage of the carbon ring introduces more than one extra $\mathrm{O}$ atom, compared with straightchain alkanes. However, the measured $\mathrm{O}: \mathrm{C}$ for the cyclododecane low- $\mathrm{NO}_{\mathrm{x}}$ case is the lowest among the four alkanes. The model can replicate the measured ratio only if the average oxygen number of nonvolatile compounds is decreased to three. The model prediction suggests a more effective dehydration process occurring in cyclododecane than other systems, as long as the AMS measurements are comparable for the eight experiments and the matrix of functional groups is applicable for the four $\mathrm{C}_{12}$ alkanes.

Measured and predicted $\mathrm{H}: \mathrm{C}$ ratios of the SOA are shown in Fig. 7. The simulated $\mathrm{H}: \mathrm{C}$ ratios match those observed after several hours of reaction for each experiment. The reason that it still takes several hours of photooxidation to reach the gray region (uncertainties of $\mathrm{O}: \mathrm{C}$ and $\mathrm{H}: \mathrm{C}$ ) is that the oligomer formation takes time to be competitive with the oxidation reactions in both gas and particle phases, which are dominant at the beginning of the oxidation. The starting points, however, varied by $15 \%$ : the predicted $\mathrm{H}: \mathrm{C}$ ratio starts from 2 , decreasing to $\sim 1.7$, whereas AMS measurements show that the $\mathrm{H}: \mathrm{C}$ ratio is roughly constant, with an average ranging from 1.6 to 1.7 , over the course of each experiment. The functional group contributing the highest 


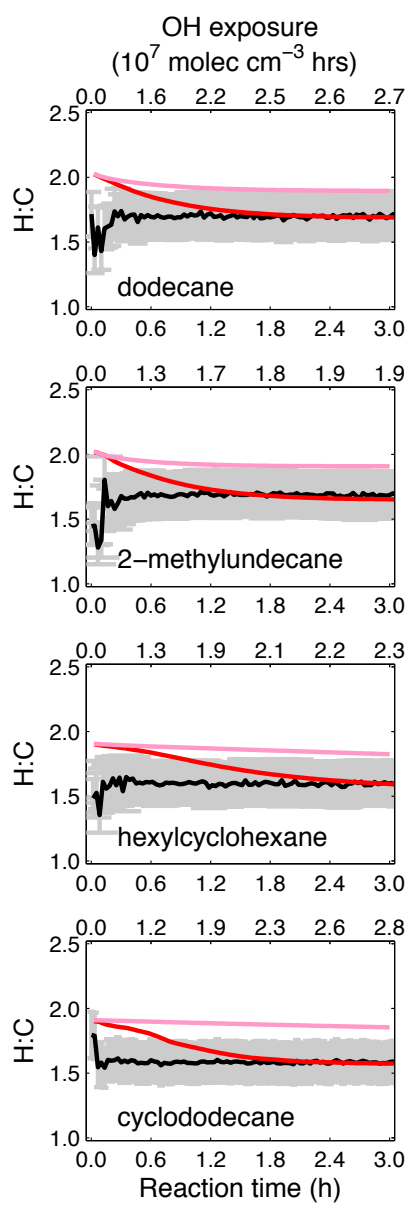

High-NOx
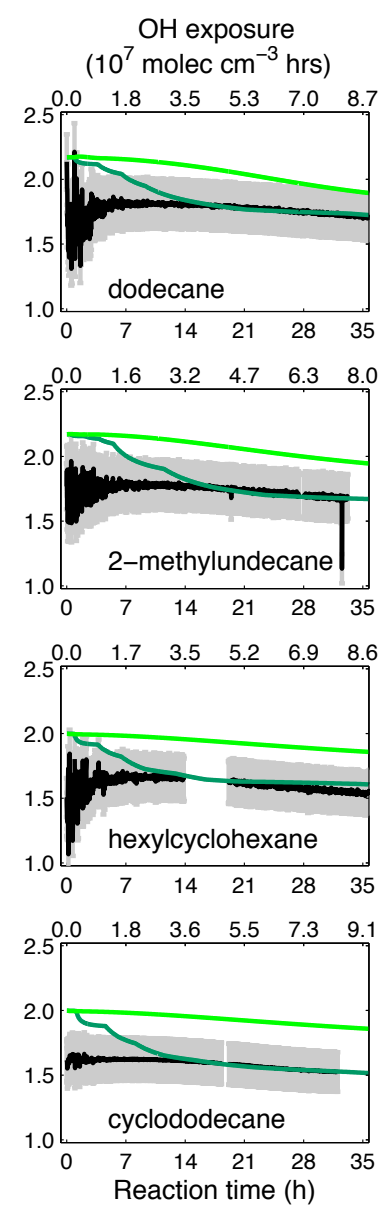

Low-NOx

Fig. 7. Simulated (colors) and observed (black) temporal profiles of particulate $\mathrm{H}: \mathrm{C}$ ratio from the photooxidation of $\mathrm{C}_{12}$ alkanes under high- (red) and low- (green) $\mathrm{NO}_{\mathrm{x}}$ conditions. Dark colors denote "sim. 1" and light colors denote "sim.2".

decrease in $\mathrm{H}$ : $\mathrm{C}$ ratio is $-\mathrm{C}=\mathrm{O}$. On the basis of the gas-phase chemistry, at least $3-\mathrm{C}=\mathrm{O}$ additions to the parent hydrocarbon are needed to reach the observed $\mathrm{H}: \mathrm{C}$ ratio. One generation of oxidation can introduce at most one $-\mathrm{C}=\mathrm{O}$ to the $\mathrm{SOA}$, as the functional groups that are most likely to induce partitioning into the particle phase are $-\mathrm{OOH}$ and $-\mathrm{ONO}_{2}$, resulting in a higher contribution to the decrease of vapor pressure than $-\mathrm{C}=\mathrm{O}$. This means that $>3$ generations of oxidation are needed to produce the "right" molecule. Note that certain combinations of functional groups, like - $\mathrm{OOH}$ and $-\mathrm{OH}$, that have sufficiently low vapor pressure to be incorporated in the particles, do not change the $\mathrm{H}: \mathrm{C}$ ratio. Therefore, products with $\mathrm{H}: \mathrm{C}$ ratio even lower than 1.7 generated via either gas- or particle- phase chemistry could exist. While we have not explicitly considered the $-\mathrm{C}(\mathrm{O}) \mathrm{OH}$ group, this group can be represented by the sum of $-\mathrm{C}=\mathrm{O}$ and $-\mathrm{OH}$. In addition, $-\mathrm{COOH}$ groups can be produced only via fragmen-

tation, which might be accompanied by an increase of vapor pressure. Thus, the contribution of $-\mathrm{COOH}$ to the chemical composition of alkane SOA is deemed less important as those of other functional groups. Gas-phase photochemistry alone cannot produce such a low $\mathrm{H}$ : C ratio measured by AMS. Dehydration processes in the particle phase, on the other hand, are necessary to obtain the desired $\mathrm{H}: \mathrm{C}$ ratio, although this process is likely not sufficiently fast to drive the $\mathrm{H}: \mathrm{C}$ ratio immediately to $\sim 1.7$ at the onset of photochemistry.

Particle-phase accretion reactions (dehydration) play an important role in order to fit the model output to the chamber generated SOA data. However, this conclusion can be biased significantly by the variations in the AMS elemental analysis. As discussed in the Supplement, AMS signals of water in both gas and particle phase occur at $\mathrm{H}_{2} \mathrm{O}^{+}(\mathrm{m} / z=$ $18), \mathrm{OH}^{+}(m / z=17)$, and $\mathrm{O}^{+}(m / z=16)$, which are also produced from organic aerosols. All of the eight alkanes experiments were carried out under dry conditions so that the interference of gas-phase water vapor is considered to be insignificant. Water present in particles or produced from dehydration reactions, however, can still bias the contribution of organic aerosols to signals of $\mathrm{H}_{2} \mathrm{O}^{+}, \mathrm{OH}^{+}$, and $\mathrm{O}^{+}$. The oxidation state, on the other hand, is insensitive to the parameters in the fragmentation table, which assign contributions of water to the three ion signals. Using the best-fit values constrained by $\mathrm{C}_{\mathrm{OA}}, \mathrm{O}: \mathrm{C}$, and $\mathrm{H}: \mathrm{C}$, the modeled temporal profiles of oxidation state tend to match the observations better; see Fig. 8. Model output with only gas-phase chemistry incorporated tends to underpredict the oxidation state. This is because the intense loss of hydrogen atoms cannot be reproduced, indicating that the dehydration pathway is still somehow necessary.

\subsection{Role of particle-phase chemistry}

Ample experimental evidence indicates the potential importance of oligomerization processes in the SOA formation. The esterification from carboxylic acids or inorganic acids and alcohols or amines is considered to be a potentially important dehydration reaction channel in the particle phase. Esters, acid anhydride, and organosulfates have been widely observed in chamber studies (Gao et al., 2004a, b; Surratt et al., 2006, 2007a, b; Szmigielski et al., 2007; Iinuma et al., $2007 \mathrm{a}, \mathrm{b})$. Other dehydration reactions, such as acetal formation from the reaction of alcohols and hemiacetals and peroxyhemiacetal formation from the reaction of peroxyhemiacetals and peroxides, have also been proposed to potentially occur within the lifetime of ambient aerosols (Ziemann and Atkinson, 2012). Acetals have been identified in SOA formed from methylglyoxal uptake recently (Yasmeen et al., 2010). To assess the role of nonoxidative particle-phase reactions on SOA formation from $\mathrm{C}_{12}$ alkanes, one may shut off the accretion reaction channel $\left(k_{\mathrm{a}}=0\right)$ and fit only $f_{v}$ and $r_{\mathrm{p}}$ to the SOA data. Although under this condition the model is capable of reproducing the observed organic aerosol growth 


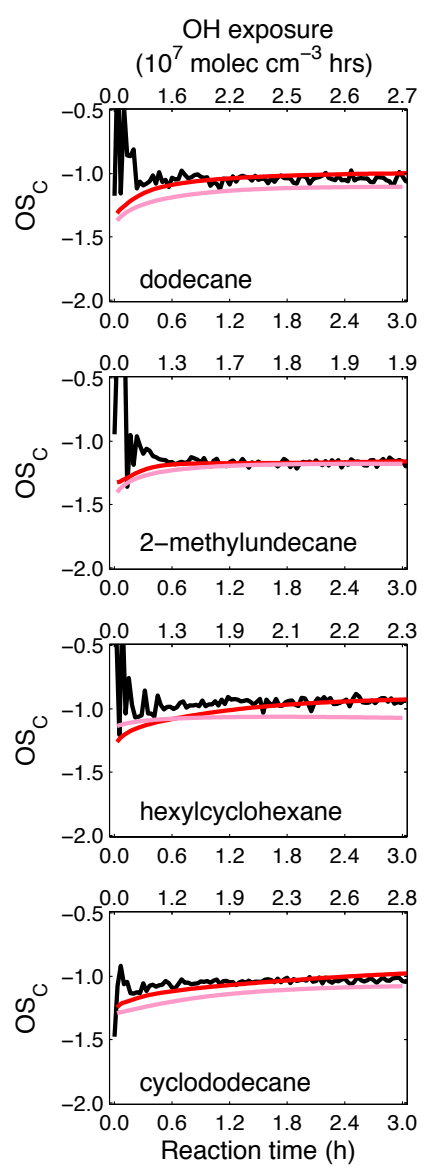

High-NOx
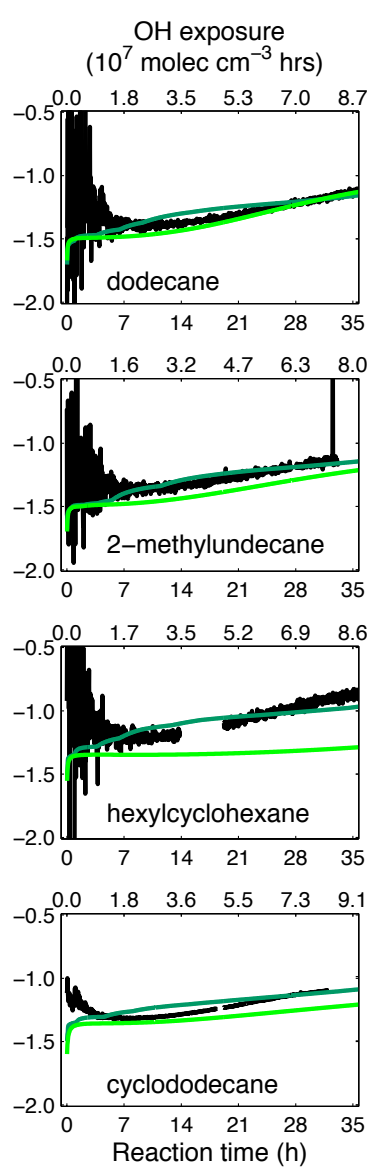

Low-NOx

Fig. 8. Simulated (colors) and observed (black) temporal profiles of particulate oxidation state $\left(\mathrm{OS}_{\mathrm{C}}\right)$ from the photooxidation of $\mathrm{C}_{12}$ alkanes under high- (red) and low- (green) $\mathrm{NO}_{\mathrm{x}}$ conditions. Dark colors denote "sim.1" and light colors denote "sim.2".

curves, $\mathrm{O}: \mathrm{C}$ and $\mathrm{H}: \mathrm{C}$ ratios are overpredicted by $35 \%$ and $30 \%$, respectively. Progressive oxidation chemistry is not capable of explaining the measured $\mathrm{O}: \mathrm{C}$ and $\mathrm{H}: \mathrm{C}$ ratios. Thus, gas-phase oxidation alone, coupled to gas-particle partitioning, does not lead to condensed phase OA with sufficiently low volatility and high oxidation state. One concludes that the nonoxidative chemistry afforded by the accretion reaction channel is required to simulate the observed oxidation state of the alkane SOA by producing essentially nonvolatile dehydrated compounds.

Particle-phase oxidative reactions constitute an additional channel in the "VOC to SOA pump". As noted, it is assumed that these reactions parallel those in the gas phase in terms of the functionalization and fragmentation pathways available, but at a rate that is a factor of $r_{\mathrm{p}}(<1)$ of the gas-phase rate. Fragmentation at each generation both in the gas and particle phases leads to a systematic cleavage of the original carbon backbone. If this cleavage is not compensated for

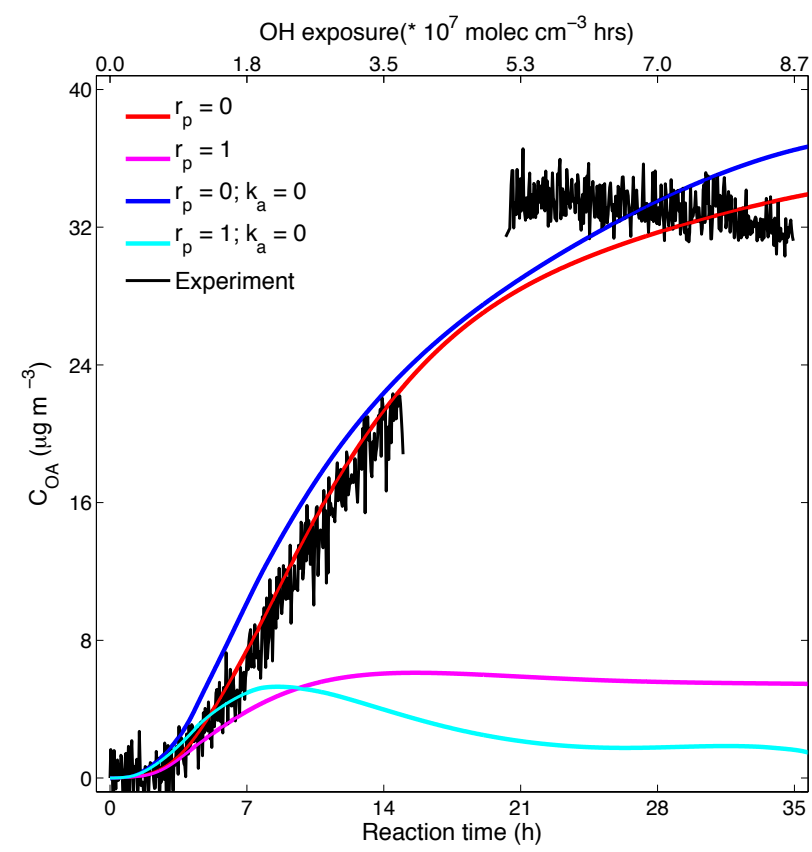

Fig. 9. Effect of particle-phase oxidative reactions on the SOA growth from the low- $\mathrm{NO}_{\mathrm{x}}$ photooxidation of dodecane. Four simulations are run here: (1) no particle-phase oxidative chemistry, as shown in red curve $\left(r_{\mathrm{p}}=0\right.$ with other parameters held at their bestfit values); (2) particle-phase oxidation reaction kinetics is same as gas phase, as shown in magenta curve $\left(r_{\mathrm{p}}=1\right.$ with other parameters held at their best-fit values); (3) no particle-phase chemistry, as shown in blue curve $\left(r_{\mathrm{p}}=0\right.$ and $k_{\mathrm{a}}=0$, with other parameters held at their best-fit values); and (4) particle-phase oxidation reaction kinetics is same as gas phase but no accretion reaction channel, as shown in canyon curve $\left(r_{\mathrm{p}}=1\right.$ and $k_{\mathrm{a}}=0$, with other parameters held at their best-fit values).

by additional functionalization, the molecules produced will have higher volatility than their precursors, and a decrease in overall organic aerosol mass occurs regardless of whether the pathway occurs in the gas or particle phase. The existence of the particle-phase oxidation channel acts to accelerate the overall SOA evolution and therefore can lead to a more rapid aging than in its absence.

Figure 9 shows the simulated organic aerosol growth from the photooxidation of dodecane under low- $\mathrm{NO}_{\mathrm{x}}$ conditions when $r_{\mathrm{p}}=0$ or 1 , with other parameters held at their best-fit values. When $r_{\mathrm{p}}=0$, the predicted organic aerosol growth is able to match the measured $\mathrm{C}_{\mathrm{OA}}$ because the $r_{\mathrm{p}}$ value for low$\mathrm{NO}_{\mathrm{x}}$ dodecane obtained from the optimization is $10^{-3}$, implying a negligible particle-phase oxidation pathway. When $r_{\mathrm{p}}=1$, the predicted $\mathrm{C}_{\mathrm{OA}}$ is less than $20 \%$ of that measured in the chamber after $35 \mathrm{~h}$ of reaction. Although the incorporation of the accretion channel increases the predicted $\mathrm{C}_{\mathrm{OA}}$, this increase is insignificant in the presence of highly effective particle-phase oxidation reactions $\left(r_{\mathrm{p}}=1\right)$. Obviously, the " $r_{\mathrm{p}}=1$ " simulation is an unrealistic case such that two 
Table 3. Comparison of the treatment of gas-phase chemistry, including functionalization and fragmentation, particle-phase chemistry, including oxidation and accretion reactions, and gas-particle partitioning between two models: (1) statistical oxidation model (SOM) and (2) functional group oxidation model (FGOM).

\begin{tabular}{|c|c|c|c|}
\hline & & SOM $^{*}$ & FGOM \\
\hline \multirow[t]{4}{*}{$\begin{array}{l}\text { Empirical } \\
\text { parameters }\end{array}$} & & $\begin{array}{l}\text { - Probability of fragmentation } \\
\mathrm{P}=c_{\text {frag }} \mathrm{O} \text { or } \mathrm{P}=(\mathrm{O}: \mathrm{C})^{m_{\mathrm{frag}}}\end{array}$ & $\begin{array}{l}\text { - Probability of fragmentation } \\
\mathrm{P}=(\mathrm{O}: \mathrm{C})^{f_{v}}\end{array}$ \\
\hline & & $\begin{array}{l}\text { - Decrease in vapor pressure } \\
\text { per O-atom added }\end{array}$ & $\begin{array}{l}\text { - Particle phase oxidation } \\
\text { rates }\end{array}$ \\
\hline & & $\begin{array}{l}\text { - Number of O-atoms added } \\
\text { per generation }\end{array}$ & $\begin{array}{l}\text { - Particle phase accretion } \\
\text { reaction rates }\end{array}$ \\
\hline & & $\begin{array}{l}\text { - Number of H-atoms lost per } \\
\text { O-atom added }\end{array}$ & $\begin{array}{l}\text { - Chemical properties of the } \\
\text { nonvolatile species }\end{array}$ \\
\hline \multirow[t]{2}{*}{$\begin{array}{l}\text { Gas-phase } \\
\text { chemistry }\end{array}$} & Func. & $\begin{array}{l}\text { - Addition of oxygen } \\
\text { - Decrease in vapor pressure }\end{array}$ & $\begin{array}{l}\text { - Addition of functional } \\
\text { groups } \\
\text { - Decrease in vapor pressure }\end{array}$ \\
\hline & Frag. & $\begin{array}{l}\text { - A function of oxygen } \\
\text { number or } \mathrm{O}: \mathrm{C} \text { ratio }\end{array}$ & - A function of $\mathrm{O}: \mathrm{C}$ ratio \\
\hline \multirow[t]{2}{*}{$\begin{array}{l}\text { Particle-phase } \\
\text { chemistry }\end{array}$} & Oxidation & $\begin{array}{l}\text { - OH radical uptake } \\
\text { coefficient is unity } \\
\text { - One extra oxygen is added } \\
\text { per generation of oxidation } \\
\text { - Fragmentation is treated the } \\
\text { same as gas phase }\end{array}$ & $\begin{array}{l}\text { - Reaction rates are best-fit } \\
\text { parameters } \\
\text { - Follows gas-phase oxidation } \\
\text { mechanisms } \\
\text { - Fragmentation is treated the } \\
\text { same as gas phase }\end{array}$ \\
\hline & Accretion & - & $\begin{array}{l}\text { - Bimolecular reaction with } \\
\text { an adjustable reaction rate } \\
\text { constant } \\
\text { - The elemental composition } \\
\text { of nonvolatile species is } \\
\text { defined by empirical } \\
\text { parameters }\end{array}$ \\
\hline
\end{tabular}

* The distribution of fragments upon fragmentation is computed in two ways: (1) a random probability for the location of $\mathrm{C}-\mathrm{C}$ bond scission, and (2) fragmentation leads to $\mathrm{C}_{n-1}$ and $\mathrm{C}_{1}$ and species.

parallel oxidation pathways with the same set of reaction rate constants exist in the gas and particle phases during SOA aging. The overall gas- and particle-phase rates of functionalization and fragmentation processes are accelerated in such a way that the decrease of volatility from the addition of functional groups cannot compensate for the increase of volatility due to the cleavage of the carbon backbone. As a result, the semivolatile products are mostly consumed during the rapid aging process to produce intermediates with a higher volatility circumventing the accumulation of the organic aerosol.

\section{The character of alkane SOA formation: comparison of FGOM and SOM}

The two semiexplicit SOA models, FGOM and SOM, employ distinct, but related, frameworks to characterize SOA properties. Both models represent functionalization and fragmentation, and each treats the fragmentation process with a tunable parameter, " $P_{\mathrm{f}}$ ", that represents the probability of fragmentation. The molar yields of smaller molecules from fragmentation processes are assumed to be randomly assigned or with only one carbon atom loss in SOM, and with only one carbon atom loss in FGOM. The functionalization channel in SOM is represented in a statistical manner. The addition of average O-atoms per generation of oxidation and the decrease of volatility per addition of O-atoms are tunable parameters, as shown in Table 3. FGOM automatically generates all possible compounds with the combination of four different functional groups and certain carbon numbers, as suggested by the generalized gas-phase chemistry. The one major difference between these two models is the treatment of particle-phase nonoxidative reactions: SOA formation and aging are driven solely by gasphase photochemistry in SOM, whereas the extent of accretion reaction channel is adjusted by four tunable parameters in FGOM. Both FGOM and SOM attempt to reproduce 

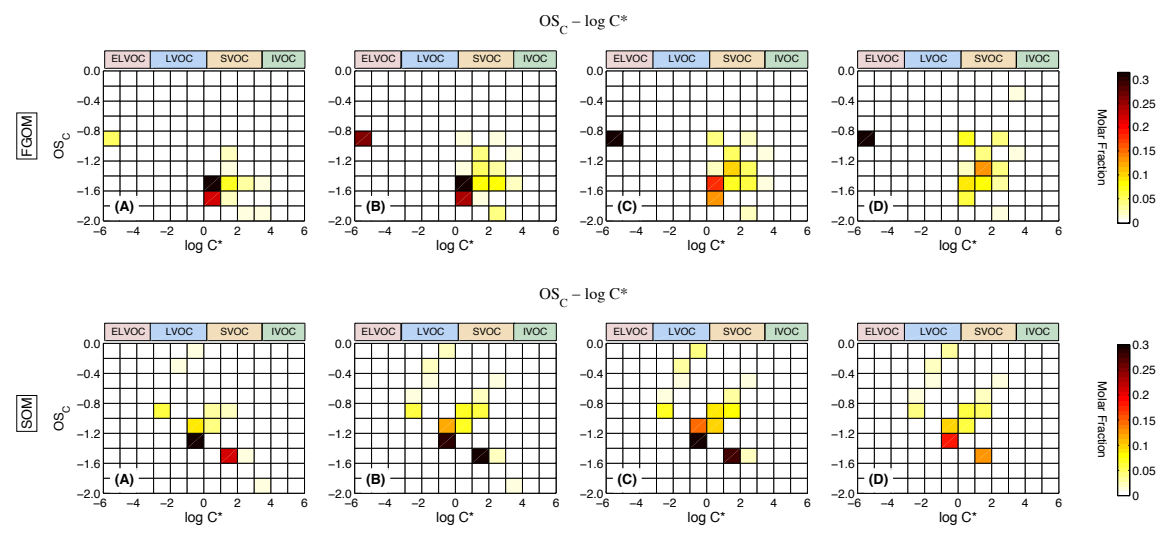

$\mathrm{OS}_{\mathrm{C}}-\log \mathrm{C}^{*}$
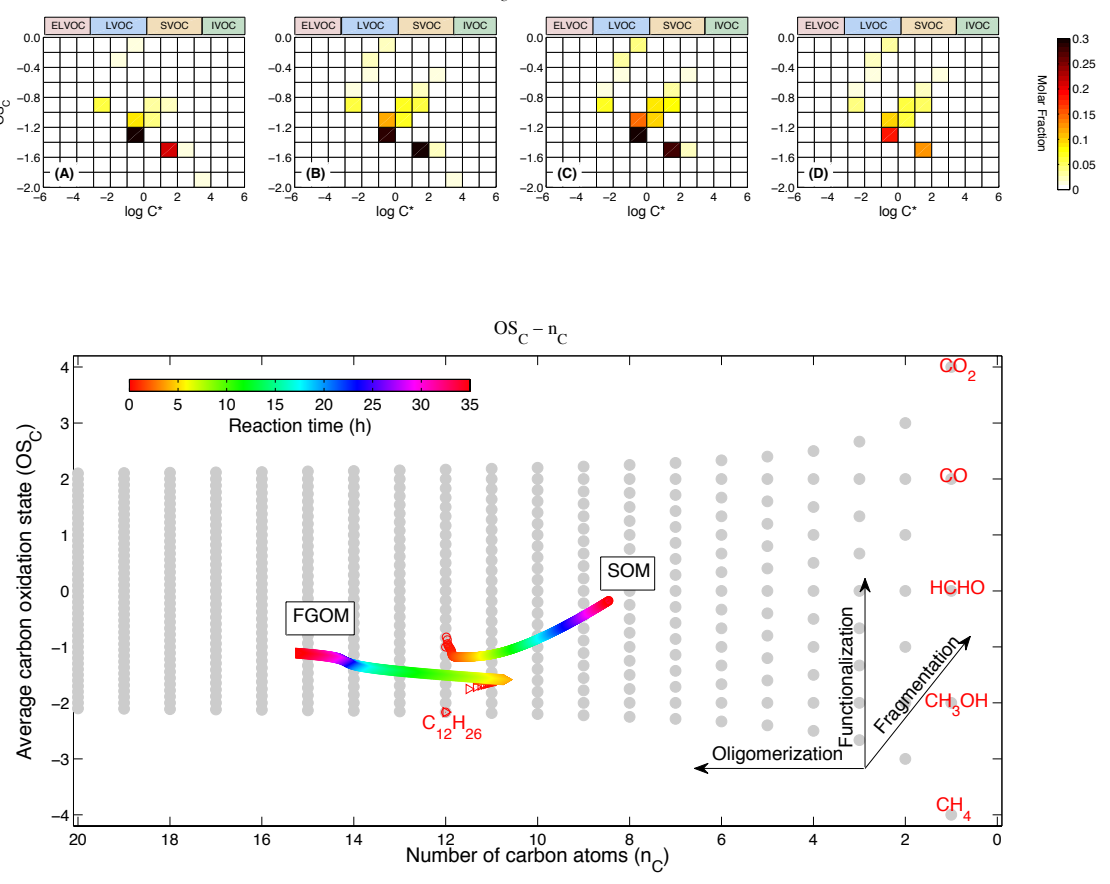

Fig. 10. Comparison of FGOM with SOM for low- $\mathrm{NO}_{\mathrm{x}}$ dodecane $\mathrm{SOA}$ formation. The upper panel is the FGOM-predicted SOA composition represented by saturation concentration and average oxidation state after 7 (A), 14 (B), 21 (C), and 28 (D) hours of reaction, respectively. The middle panel is the SOM predicted SOA composition at same time points as FGOM. The lower panel is the simulated results of these two models in $n_{\mathrm{C}}$ vs. $\mathrm{OS}_{\mathrm{C}}$ space.

the observed-chamber-generated SOA properties (organic aerosol mass, $\mathrm{O}: \mathrm{C}$, and $\mathrm{H}: \mathrm{C}$ ratio) through optimal fitting of the empirical parameters in each model - e.g., Figs. 4, 6, 7, and 8 in this study and Figs. 1 and 3 in Cappa et al. (2013) - to the same set of alkane SOA data generated from the Caltech environmental chamber. Comparison between these two sheds light on understanding the sensitivity of SOA growth to different reaction pathways in gas and particle phases.

One can map the simulation results of these two models onto the $\mathrm{OS}_{\mathrm{C}}-\log \mathrm{C}^{*}$ space (Fig. 10). Atmospheric aging leads to increased functionality on the $\mathrm{C}_{12}$ skeleton and thus higher average oxidation state, which is reflected by both models. The SOM predicts $\mathrm{OS}_{\mathrm{C}}(-1.1 \sim-0.6)$ vs. FGOM $(-1.8 \sim-1.0)$. The AMS measured $\mathrm{OS}_{\mathrm{C}}(=2 \times \mathrm{O}: \mathrm{C}-$ $\mathrm{H}: \mathrm{C}$ ) of dodecane $\mathrm{SOA}$ is bounded by these two predictions, ranging from -1.2 to -1 . The underestimation of $\mathrm{OS}_{\mathrm{C}}$ by FGOM at the early stage is largely due to the starting point of the $\mathrm{H}: \mathrm{C}$ ratio, as discussed in Sect. 3.2. The SOM-generated $\mathrm{OS}_{\mathrm{C}}$ is shaped primarily by the simulated $\mathrm{O}: \mathrm{C}$ ratio since the adjustable parameter " $\mathrm{H}$-atom loss per O-atom added" is determined as a constant. The overprediction of $\mathrm{OS}_{\mathrm{C}}$ by SOM thus results from the overprediction of the $\mathrm{O}: \mathrm{C}$ ratio at the end of the simulation.

The SOM-simulated composition exhibits effective saturation concentrations $\left(\log C^{*}\right)$ of monomers that are, on average, one order of magnitude lower than those in FGOM. Values of the best-fit parameters in SOM for the low- $\mathrm{NO}_{\mathrm{x}}$ dodecane case can be found in Table 2 in Cappa et al. (2013). The decrease of vapor pressure upon the addition of one oxygen on a log scale $(\Delta \mathrm{LVP}), 2.20$, corresponds to the addition of an $-\mathrm{OH}$ group, which leads to the largest decrease of vapor pressure per oxygen atom according to the vapor pressure prediction models "SIMPOL.1" and "EVAPORATION". This $\triangle$ LVP value suggests that in order to reproduce the observed concentration of chamber-generated organic aerosol, the gas-phase chemistry should proceed such that the addition of any functional group on the carbon chain results in a decrease of the logarithm of vapor pressure by 


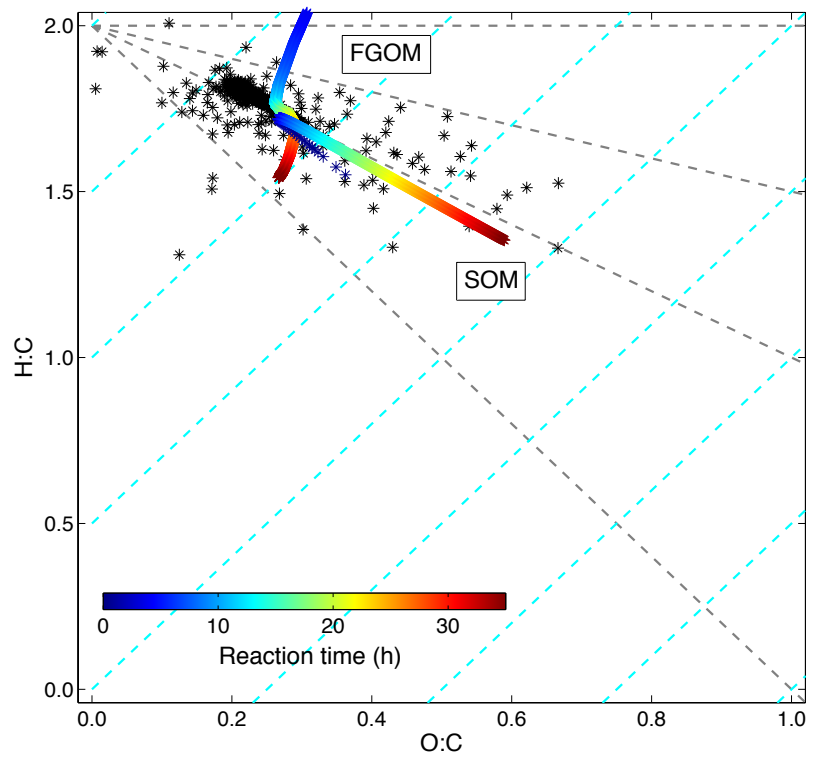

Fig. 11. van Krevelen diagram. FGOM and SOM simulated $\mathrm{H}: \mathrm{C}$ vs. O : $\mathrm{C}$ temporal profile, together with chamber measured data (black asterisks) for low- $\mathrm{NO}_{\mathrm{x}}$ dodecane system. Black dashed lines represent changes in slopes upon the addition of different functional groups (from top to bottom: $-\mathrm{OH}, \mathrm{NA},-\mathrm{COOH}$ or $-\mathrm{C}=\mathrm{O}$ plus $-\mathrm{OH}$, and $-\mathrm{C}=\mathrm{O}$ ). Canyon dash lines map the oxidation state along the van Krevelen diagram.

2.20 per oxygen atom. The vapor pressure estimation module developed for use in FGOM for the alkanes constrains the $\triangle \mathrm{LVP}$ values per $\mathrm{O}$-atom addition to range from 0.79 to 1.97 upon the addition of the array of functional groups (the predicted decreases of the logarithm of vapor pressure (atm) upon the addition of $-\mathrm{OOH},-\mathrm{ONO}_{2},-\mathrm{OH}$, and $-\mathrm{C}=\mathrm{O}$ are $2.83,2.36,1.97$, and 1.20 , respectively). This is confirmed as the probability of fragmentation in SOM $\left(m_{\text {frag }}=0.077\right)$ is higher than that in FGOM $\left(f_{v}=0.61\right.$ with accretion channel and $f_{v}=0.77$ without accretion channel).

The simulated SOA chemical compositions are also shown in the $\mathrm{OS}_{C}-n_{\mathrm{C}}$ space in Fig. 10. The average carbon numbers predicted by these two models cover distinctly different ranges. The temporal profile of aerosol $n_{\mathrm{C}}$ predicted by FGOM decreases initially to $\sim 10.6$ and then increases to $\sim 15.2$ at the end of the experiment. In the FGOM, two principal pathways govern the dynamics of carbon number: $\mathrm{C}-\mathrm{C}$ bond cleavage and particle-phase accretion reactions. The degree of $\mathrm{C}-\mathrm{C}$ bond cleavage determines the lower limit of the average SOA carbon number, whereas the extent of accretion reactions sets the carbon-number upper limit. The optimal FGOM fitting results suggest that oligomerization in the particle phase is required to predict the observed oxidative aging of dodecane SOA, in particular the evolution of the $\mathrm{O}: \mathrm{C}$ and $\mathrm{H}: \mathrm{C}$.

Why do these two approaches that more or less equally capture the chamber-generated SOA properties exhibit such different oxidation trajectories in $\mathrm{OS}_{\mathrm{C}}-n_{\mathrm{C}}$ space? While FGOM exhibits the pull of oligomers, the oxidation trajectory generated by SOM progressively evolves in a direction that involves significant formation of highly oxidized small fragments. In the SOM, the individual species are characterized by the average carbon and oxygen number $\left(n_{\mathrm{O}} / n_{\mathrm{C}}\right.$ pairs), pairs that do not necessarily correspond to actual compounds since functional group information is not explicitly simulated. Again, for the dodecane low- $\mathrm{NO}_{\mathrm{x}}$ case, the $\triangle \mathrm{LVP}$ and $[1 \mathrm{O}, 2 \mathrm{O}, 3 \mathrm{O}, 4 \mathrm{O}]$ values are 2.2 and $[0.79,0.17,0.03$, $0.0]$, respectively, meaning that upon one generation of oxidation, the average number of oxygens added is 1.22 and the total decrease of vapor pressure on a log scale is 2.7 , which equals the addition of approximately $1.3-\mathrm{OH}, 1.2-\mathrm{OOH}$, $1.2-\mathrm{ONO}_{2}$ or $2.4-\mathrm{C}=\mathrm{O}$ groups. This intense decrease of volatility upon only one generation allows the formation of small highly oxygenated fragments but with sufficiently low volatilities to contribute appreciably to the particle phase. As noted, these small fragments, as represented by $n_{\mathrm{O}} / n_{\mathrm{C}}$ pairs, are not actual products reflected in current gas-phase photochemical mechanisms. However, their presence in the particle phase in a significant amount shifts the oxidation trajectory to the upper-right corner in $\mathrm{OS}_{\mathrm{C}}-n_{\mathrm{C}}$ space.

Neither FGOM nor SOM can exactly describe the actual oxidation trajectory of alkane SOA because the chamber generated constraints are limited. However, information of the role of particle-phase chemistry can be extracted by comparing these two model outputs. In SOM, the measured van Krevelen slope is used to determine the $\mathrm{H}$-atom loss per Oatom added with other six parameters held at their best-fit values adjusted by $\mathrm{C}_{\mathrm{OA}}$ and $\mathrm{O}: \mathrm{C}$, as opposed to fitting all of the free parameters together to $\mathrm{C}_{\mathrm{OA}}, \mathrm{O}: \mathrm{C}$, and $\mathrm{H}: \mathrm{C}$. As shown in Fig. 11, the best-fit value of $\mathrm{H}$-atom loss per Oatom added is 1.77 in SOM in the dodecane low- $\mathrm{NO}_{\mathrm{x}}$ case, indicating the formation of an unsaturated carbon bond upon one step of oxidation. The $\triangle \mathrm{LVP}$ value per O-atom added, however, indicates that the functional group likely to be added is $-\mathrm{OH}$, with a van Krevelen slope of 1. This discrepancy reflects the fact that the best-fit parameters in the SOM cannot reproduce the observed $\mathrm{O}: \mathrm{C}$ or $\mathrm{H}: \mathrm{C}$ ratios without a dehydration reaction channel. This returns us to the fundamental question: to what extent can gas-phase chemistry alone account for the SOA formation? Several products generated by the gas-phase mechanism in FGOM, detected in the chamber dodecane low- $\mathrm{NO}_{\mathrm{x}}$ experiments (Yee et al., 2012), have sufficiently low volatility to form a substantial amount of organic aerosol mass. Nonetheless, the inescapable conclusion is that the presence of accretion reactions is necessary to reconcile both the disagreement between the indications of the best-fit parameters in SOM and the inability of the FGOM to reproduce the measured elemental composition based solely on gas-phase chemistry. Evaluating the extent to which particle-phase chemistry is important for virtually all SOA parent VOCs awaits a more complete understanding of gas-phase chemistry and measured SOA chemical properties. 
Supplementary material related to this article is available online at: http://www.atmos-chem-phys.net/13/ 5907/2013/acp-13-5907-2013-supplement.pdf.

Acknowledgements. This work was supported by US Department of Energy grant DE-SC0006626. Helpful discussions with Chris Cappa are appreciated.

Edited by: I. Riipinen

\section{References}

Aiken, A. C., DeCarlo, P. F., and Jimenez, J. L.: Elemental analysis of organic species with electron ionization high-resolution mass spectrometry, Anal. Chem., 79, 8350-8358, 2007.

Aiken, A. C., DeCarlo, P. F., Kroll, J. H., Worsnop, D. R., Huffman, J. A., Docherty, K. S., Ulbrich, I. M., Mohr, C., Kimmel, J. R., Sueper, D., Sun, Y., Zhang, Q., Trimborn, A., Northway, M., Ziemann, P. J., Canagaratna, M. R., Onasch, T. B., Alfarra, M. R., Prevot, A. S. H., Dommen, J., Duplissy, J., Metzger, A., Baltensperger, U., and Jimenez, J. L.: O/C and OM/OC ratios of primary, secondary, and ambient organic aerosols with high-resolution time-of-flight aerosol mass spectrometry, Environ. Sci. Technol., 42, 4478-4485, 2008.

Atkinson, R.: Atmospheric chemistry of VOCs and $\mathrm{NO}_{\mathrm{x}}$, Atmos. Environ., 36, 1483-1498, 2000.

Aumont, B., Szopa, S., and Madronich, S.: Modelling the evolution of organic carbon during its gas-phase tropospheric oxidation: development of an explicit model based on a self generating approach, Atmos. Chem. Phys., 5, 2497-2517, doi:10.5194/acp-52497-2005, 2005.

Aumont, B., Valorso, R., Mouchel-Vallon, C., Camredon, M., LeeTaylor, J., and Madronich, S.: Modeling SOA formation from the oxidation of intermediate volatility n-alkanes, Atmos. Chem. Phys., 12, 7577-7589, doi:10.5194/acp-12-7577-2012, 2012.

Barsanti, K. C., Smith, J. N., and Pankow, J. F.: Application of the $\mathrm{np}+\mathrm{mP}$ modeling approach for simulating secondary organic particulate matter formation from $\alpha$-pinene oxidation, Atmos. Environ., 45, 6812-6819, 2011.

Bloss, C., Wagner, V., Jenkin, M. E., Volkamer, R., Bloss, W. J., Lee, J. D., Heard, D. E., Wirtz, K., Martin-Reviejo, M., Rea, G., Wenger, J. C., and Pilling, M. J.: Development of a detailed chemical mechanism (MCMv3.1) for the atmospheric oxidation of aromatic hydrocarbons, Atmos. Chem. Phys., 5, 641-664, doi:10.5194/acp-5-641-2005, 2005.

Camredon, M. and Aumont, B.: Asessment of vapor pressure estimation methods for secondary organic aerosol modeling, Atmos. Environ., 40, 2105-2116, 2006.

Camredon, M., Aumont, B., Lee-Taylor, J., and Madronich, S.: The SOA/VOC/NOx system: an explicit model of secondary organic aerosol formation, Atmos. Chem. Phys., 7, 5599-5610, doi:10.5194/acp-7-5599-2007, 2007.

Capouet, M. and Müller, J.-F.: A group contribution method for estimating the vapour pressures of $\alpha$-pinene oxidation products, Atmos. Chem. Phys., 6, 1455-1467, doi:10.5194/acp-6-1455-2006, 2006.
Cappa, C. D. and Wilson, K. R.: Multi-generation gas-phase oxidation, equilibrium partitioning, and the formation and evolution of secondary organic aerosol, Atmos. Chem. Phys., 12, 9505-9528, doi:10.5194/acp-12-9505-2012, 2012.

Cappa, C. D., Zhang, X., Loza, C. L., Craven, J. S., Yee, L. D., and Seinfeld, J. H.: Application of the Statistical Oxidation Model (SOM) to Secondary Organic Aerosol formation from photooxidation of $\mathrm{C}_{12}$ alkanes, Atmos. Chem. Phys., 13, 1591-1606, doi:10.5194/acp-13-1591-2013, 2013.

Chacon-Madrid, H. J., Murphy, B. N., Pandis, S. N., and Donahue, N. M.: Simulations of smog-chamber experiments using the twodimensional volatility basis set: linear oxygenated precursors, Environ. Sci. Technol., 46, 11179-11186, 2012.

Chen, Q., Liu, Y. J., Donahue, N. M., Shilling, J. E., and Martin, S. T.: Particle-phase chemistry of secondary organic material: modeled compared to measured $\mathrm{O}: \mathrm{C}$ and $\mathrm{H}: \mathrm{C}$ elemental ratios provide constraints, Environ. Sci. Technol., 45, 4763-4770, 2011.

Chhabra, P. S., Flagan, R. C., and Seinfeld, J. H.: Elemental analysis of chamber organic aerosol using an aerodyne high-resolution aerosol mass spectrometer, Atmos. Chem. Phys., 10, 4111-4131, doi:10.5194/acp-10-4111-2010, 2010.

Craven, J. S., Yee, L. D., Ng, N. L., Canagaratna, M. R., Loza, C. L., Schilling, K. A., Yatavelli, R. L. N., Thornton, J. A., Ziemann, P. J., Flagan, R. C., and Seinfeld, J. H.: Analysis of secondary organic aerosol formation and aging using positive matrix factorization of high-resolution aerosol mass spectra: application to the dodecane low- $\mathrm{NO}_{\mathrm{x}}$ system, Atmos. Chem. Phys., 12, 1179511817, doi:10.5194/acp-12-11795-2012, 2012.

Compernolle, S., Ceulemans, K., and Müller, J.-F.: EVAPORATION: a new vapour pressure estimation methodfor organic molecules including non-additivity and intramolecular interactions, Atmos. Chem. Phys., 11, 9431-9450, doi:10.5194/acp-119431-2011, 2011.

DeCarlo, P. F., Dunlea, E. J., Kimmel, J. R., Aiken, A. C., Sueper, D., Crounse, J., Wennberg, P. O., Emmons, L., Shinozuka, Y., Clarke, A., Zhou, J., Tomlinson, J., Collins, D. R., Knapp, D., Weinheimer, A. J., Montzka, D. D., Campos, T., and Jimenez, J. L.: Fast airborne aerosol size and chemistry measurements above Mexico City and Central Mexico during the MILAGRO campaign, Atmos. Chem. Phys., 8, 4027-4048, doi:10.5194/acp-84027-2008, 2008.

Donahue, N. M., Robinson, C. O., and Pandis, S. N.: Coupled partitioning, dilution, and chemical aging of semivolatile organics, Environ. Sci. Technol., 40, 2635-2643, 2006.

Donahue, N. M., Epstein, S. A., Pandis, S. N., and Robinson, A. L.: A two-dimensional volatility basis set: 1. organic-aerosol mixing thermodynamics, Atmos. Chem. Phys., 11, 3303-3318, doi:10.5194/acp-11-3303-2011, 2011.

Donahue, N. M., Kroll, J. H., Pandis, S. N., and Robinson, A. L.: A two-dimensional volatility basis set - Part 2: Diagnostics of organic-aerosol evolution, Atmos. Chem. Phys., 12, 615-634, doi:10.5194/acp-12-615-2012, 2012 a.

Donahue, N. M., Henry, K. M., Mentel, T. F., Kiendler-Scharr, A., Spindler, C., Bohn, B., Brauers, T., Dorn, H. P., Fuchs, H., Tillmann, R., Wahner, A., Saathoff, H., Naumann, K.-H., Möhler, O., Leisner, T., Müller, L., Reinning, M.-C., Hoffman, T., Salo, K., Hallquist, M., Frosch, M., Bilde, M., Tritscher, T., Barmet, P., Praplan, A. P., DeCarlo, P. F., Domenn, J., Prévôt, A. S. H., and Baltensperger, U.: Aging of biogenic secondary organic aerosol 
via gas-phase $\mathrm{OH}$ radical reactions, P. Natl. Acad. Sci., 109, 13503-13508, 2012b.

Gao, S., Keywood, M., Ng, N. L., Surratt, J., Varutbangkul, B., Bahreini, R., Flagan, R. C., and Seinfeld, J. H.: Low-molecularweight and oligomeric components in secondary organic aerosol form the ozonolysis of cycloalkenes and $\alpha$-pinene, J. Phys. Chem. A., 108, 10147-10164, 2004a.

Gao, S., Ng, N. L., Keywood, M., Varutbangkul, V., Bahreini, R., Nenes, A., He, J. W., Yoo, K. Y., Beauchamp, J. L., and Hodyss, R. P.: Particle phase acidity and oligomer formation from secondary organic aerosol, Environ. Sci. Technol., 38, 6582-6589, 2004b.

George, I. J., Slowik, J., and Abbatt, J. P. D.: Chemical aging of ambient organic aerosol from heterogeneous reaction with hydroxyl radicals, Geophys. Res. Lett., 35, L13811, doi:10.1029/2008GL033884, 2008.

Heald, C. L., Jacob, D. J., Park, R. J., Russell, L. M., Huebert, B. J., Seinfeld, J. H., Lia, H., and Weber, R. J.: A large organic aerosol source in the free troposphere missing from current models, Geophys. Res. Lett., 32, L18809, doi:10.1029/2005GL023831, 2005.

Heald, C. L., Jacob, D. J., Turquety, S., Hudman, R. C., Weber, R. J., Sullivan, A. P., Peltier, R. E., Atlas, E. L., deGouw, J. A., Warneke, C., Holloway, J. S., Newman, J. A., Flocke, F. M., and Seinfeld, J. H.: Concentrations and sources of organic carbon aerosols in the free troposphere over North American, J. Geophys. Res., 111, D23S47, doi:10.1029/2006JD007705, 2006.

Iinuma, Y., Müller, C., Berndt, T., Böge, O., Claeys, M., Herrmann, $H$.: Evidence for the existence of organosulfates from $\beta$-pinene ozonolysis in ambient secondary organic aerosol, Environ. Sci. Technol., 41, 6678-6683, 2007a.

Iinuma, Y., Müller, C., Böge, O., Gnauk, T., and Herrmann, H.: The formation of organic sulfate esters in the limonene ozonlysis secondary organic aerosol (SOA) under acidic conditions, Atmos. Environ., 41, 5571-5583, 2007b.

Jenkin, M. E., Saunders, S. M., and Pilling, M. J.: The tropospheric degradation of volatile organic compounds: a protocol for mechanism development, Atmos. Environ., 31, 81-104, 1997.

Jimenez, J. L., Canagaratna, M. R., Donahue, N. M., Prevot, A. S. H., Zhang, Q., Kroll, J. H., DeCarlo, P. F., Allan, J. D., Coe, H., Ng, N. L., Aiken, A. C., Docherty, K. S., Ulbrich, I. M., Grieshop, A. P., Robinson, A. L., Duplissy, J., Smith, J. D., Wilson, K. R., Lanz, V. A., Hueglin, C., Sun, Y. L., Tian, J., Laaksonen, A., Raatikainen, T., Rautiainen, J., Vaattovaara, P., Ehn, M., Kulmala, M., Tomlinson, J. M., Collins, D. R., Cubison, M. J., Dunlea, E. J., Huffman, J. A., Onasch, T. B., Alfarra, M. R., Williams, P. I., Bower, K., Kondo, Y., Schneider, J., Drewnick, F., Borrmann, S., Weimer, S., Demerjian, K., Salcedo, D., Cottrell, L., Griffin, R., Takami, A., Miyoshi, T., Hatakeyama, S., Shimono, A., Sun, J. Y., Zhang Y. M., Dzepina, K., Kimmel, J. R., Sueper, D., Jayne, J. T., Herndon, S. C., Trimborn, A. M., Williams, L. R., Wood, E. C., Middlebrook, A. M., Kolb, C. E., Baltensperger, U., and Worsnop, D. R.: Evolution of organic aerosols in the atmosphere, Science, 326, 1525-1529, 2009.

Knopf, D. A., Anthony, L. M., and Bertram, A. K.: Reactive uptake of $\mathrm{O}_{3}$ by multicomponent and multiphase mixtures containing oleic acid, J. Phys. Chem. A, 109, 5579-5589, 2005.

Kroll, J. H. and Seinfeld, J. H.: Chemistry of secondary organic aerosol: Formation and evolution of low-volatility organics in the atmosphere, Atmos. Environ., 42, 3593-3624, 2008.
Kroll, J. H., Smith, J. D., Che, D. L., Kessler, S. H., Worsnop, D. R., and Wilson, K. R.: Measurement of fragmentation and functionalization pathways in the heterogeneous oxidation of oxidized organic aerosol, Phys. Chem. Chem. Phys., 11, 8005-8014, 2009.

Kroll, J. H., Donahue, N. M., Jimenez, J. L., Kessler, S. H., Canagaratna, M. R., Wilson, K. R., Altieri, K. E., Mazzoleni, L. R., Wozniak, A. S., Bluhm, H., Mysak, E. R., Smith, J. D., Charles, E. K., and Worsnop, D. R.: Carbon oxidation state as a metric for describing the chemistry of atmospheric organic aerosol, Nature Chem., 3, 133-139, 2011.

Kwok, E. S. C. and Atkinson, R.: Estimation of hydroxyl radical reaction rate constants for gas-phase organic compounds using a structure-reactivity relationship: An update, Atmos. Enviton., 29, 1685-1695, 1995.

Lambe, A. T., Miracolo, M. A., Hennigan, C. J., Robinson, A. L., and Donahue, N. M.: Effective rate constants and uptake coefficients for the reactions of organic molecular markers (nalkanes, hopanes, and steranes) in motor oil and diesel primary organic aerosols with hydroxyl radicals, Environ. Sci. Technol., 43, 8794-8800, 2009.

Lee-Taylor, J., Madronich, S., Aumont, B., Baker, A., Camredon, M., Hodzic, A., Tyndall, G. S., Apel, E., and Zaveri, R. A.: Explicit modeling of organic chemistry and secondary organic aerosol partitioning for Mexico City and its outflow plume, Atmos. Chem. Phys., 11, 13219-13241, doi:10.5194/acp-1113219-2011, 2011.

MathWorks. MATLAB, 2002.

Murphy, D. M., Cziczo, D. J., Hudson, P. K., and Thomson, D. S.: Carbonaceous material in aerosol particles in the lower stratosphere and tropopause region, J. Geophys. Res., 112, D04203, doi:10.1029/2006JD007297, 2007.

Murphy, B. N., Donahue, N. M., Fountoukis, C., and Pandis, S. N.: Simulating the oxygen content of ambient organic aerosol with the 2D volatility basis set, Atmos. Chem. Phys., 11, 7859-7873, doi:10.5194/acp-11-7859-2011, 2011.

Murphy, B. N., Donahue, N. M., Fountoukis, C., Dall'Osto, M., O'Dowd, C., Kiendler-Scharr, A., and Pandis, S. N.: Functionalization and fragmentation during ambient organic aerosol aging: application of the 2-D volatility basis set to field studies, Atmos. Chem. Phys., 12, 10797-10816, doi:10.5194/acp-1210797-2012, 2012.

Ng, N. L., Canagaratna, M. R., Zhang, Q., Jimenez, J. L., Tian, J., Ulbrich, I. M., Kroll, J. H., Docherty, K. S., Chhabra, P. S., Bahreini, R., Murphy, S. M., Seinfeld, J. H., Hildebrandt, L., Donahue, N. M., DeCarlo, P. F., Lanz, V. A., Prévôt, A. S. H., Dinar, E., Rudich, Y., and Worsnop, D. R.: Organic aerosol components observed in Northern Hemispheric datasets from Aerosol Mass Spectrometry, Atmos. Chem. Phys., 10, 46254641, doi:10.5194/acp-10-4625-2010, 2010.

Ng, N. L., Canagaratna, M. R., Jimenez, J. L., Chhabra, P. S., Seinfeld, J. H., and Worsnop, D. R.: Changes in organic aerosol composition with aging inferred from aerosol mass spectra, Atmos. Chem. Phys., 11, 6465-6474, doi:10.5194/acp-11-64652011, 2011.

Odum, J. R., Hoffmann, T., Bowman, F., Collins, D., Flagan, R. C., and Seinfeld, J. H.: Gas/particle partitioning and secondary organic aerosol yields, Environ. Sci. Technol., 30, 2580-2585, 1996. 
Pankow, J. F. and Asher, W. E.: SIMPOL.1: a simple group contribution method for predicting vapor pressures and enthalpies of vaporization of multifunctional organic compounds, Atmos. Chem. Phys., 8, 2773-2796, doi:10.5194/acp-8-27732008, 2008.

Pankow, J. F. and Barsanti, K. C.: The carbon number-polarity grid: A means to manage the complexity of the mix of organic compounds when modeling atmospheric organic particulate matter, Atmos. Environ., 43, 2829-2835, 2009.

Paulot, F., Crounse, J. D., Kjaergaard, G., Andreas, K. Clair, J. M. S., Seinfeld, J. H., and Wennberg, P. O.: Unexpected epoxide formation in the gas-phase photooxidation of isoprene, Nature, 325 , 730-733, 2009.

Ravishankara, A. R.: Heterogeneous and multiphase chemistry in the troposphere, Science, 276, 1058-1065, 1997.

Robinson, A. L., Donahue, N. M., Shrivastava, M. K., Weitkamp, E. A., Sage, A. M., Grieshop, A. P., Lane, T. E., Pierce, J. R., and Pandis, S. N.: Rethinking organic aerosols: Semivolatile emissions and photochemical aging, Science, 315, 1259-1262, 2007.

Saunders, S. M., Jenkin, M. E., Derwent, R. G., and Pilling, M. J.: Protocol for the development of the Master Chemical Mechanism, MCM v3 (Part A): tropospheric degradation of nonaromatic volatile organic compounds, Atmos. Chem. Phys., 3, 161-180, doi:10.5194/acp-3-161-2003, 2003.

Shiraiwa, M., Ammann, M., Koop, T., and Pöschl, U.: Gas uptake and chemical aging of semisolid organic aerosol particles, P. Natl. Acad. Sci., 108, 11003-11008, 2011.

Surratt, J. D., Murphy, S. M., Kroll, J. H., Ng, N. L., Hilderbrandt, L., Sorroshian, A., Szmigielski, R., Vermeylen, R., Maenhaut, W., Claeys, M., Flagan, R. C., and Seinfeld, J. H.: Chemical composition of secondary organic aerosol formed from the photooxidation of isoprene, J. Phys. Chem., A., 110, 9665-9690, 2006.

Surratt, J. D., Kroll, J. H., Kleindienst, T. E., Edney, E. O., Claeys, M., Sorooshian, A., Ng, N. L., Offenberg, J. H., Lewandowski, M., Jaoui, M., Flagan, R. C., and Seinfeld, J. H.: Evidence for organosulfates in secondary organic aerosol, Environ. Sci. Technol., 41, 517-527, 2007a.

Surratt, J. D., Lewandowski, M., Offenberg, J. H., Jaoui, M., Kleindienst, T. E., Edney, E. O., and Seinfeld, J. H.: Effect of acidity on secondary organic aerosol formation from isoprene, Environ. Sci. Technol., 41, 5363-5369, 2007b.

Szmigielski, R., Surratt, J. D., Vermeylen, R., Szmigielska, K., Kroll, J. H., Ng, N. L., Murphy, S. M., Sorooshian, A., Seinfeld, J. H., and Claeys, M.: Characterization of 2-methylglyceric acid oligomers in secondary organic aerosol formed from the photooxidation of isoprene using trimethylsilylation and gas chromatography/ion trap mass spectrometry, J. Mass Spectrom., 42, 101-116, 2007.
Tsigaridis, K. and Kanakidou, M.: Global modelling of secondary organic aerosol in the troposphere: a sensitivity analysis, Atmos. Chem. Phys., 3, 1849-1869, doi:10.5194/acp-3-1849-2003, 2003.

Valorso, R., Aumont, B., Camredon, M., Raventos-Duran, T., Mouchel-Vallon, C., Ng, N. L., Seinfeld, J. H., Lee-Taylor, J., and Madronich, S.: Explicit modelling of SOA formation from $\alpha$-pinene photooxidation: sensitivity to vapour pressure estimation, Atmos. Chem. Phys., 11, 6895-6910, doi:10.5194/acp-116895-2011, 2011.

Volkamer, R., Jimenez, J. L., sanMartini, F., Dzepina, K., Zhang, Q., Salcedo, D., Molina, L. T., Worsnop, D. R., and Molina, M. J.: Secondary organic aerosol formation from anthropogenic air pollution: Rapid and higher than expected, Geophys. Res. Lett., 33, L17811, doi:10.1029/2006GL026899, 2006.

Yee, L. D., Craven, J. S., Loza, C. L., Schilling, K. A., Ng, N. L., Canagaratna, M. R., Ziemann, P. J., Flagan, R. C., and Seinfeld, J. H.: Secondary organic aerosol formation from low- $\mathrm{NO}_{\mathrm{x}}$ photooxidation of dodecane: evolution of multigeneration gas-phase chemistry and aerosol formation, J. Phys. Chem. A, 116, 62116230, 2012.

Yasmeen, F., Sauret, N., Gal, J.-F., Maria, P.-C., Massi, L., Maenhaut, W., and Claeys, M.: Characterization of oligomers from methylglyoxal under dark conditions: a pathway to produce secondary organic aerosol through cloud processing during nighttime, Atmos. Chem. Phys., 10, 3803-3812, doi:10.5194/acp-103803-2010, 2010.

Zahardis, J. and Petrucci, G. A.: The oleic acid-ozone heterogeneous reaction system: products, kinetics, secondary chemistry, and atmospheric implications of a model system - a review, Atmos. Chem. Phys., 7, 1237-1274, doi:10.5194/acp-7-1237-2007, 2007.

Ziemann, P. J. and Atkinson, R.: Kinetics, products, and mechanisms of secondary organic aerosol formation, Chem. Soc. Rev., 41, 6582-6605, 2012.

Zuend, A. and Seinfeld, J. H.: Modeling the gas-particle partitioning of secondary organic aerosol: the importance of liquidliquid phase separation, Atmos. Chem. Phys., 12, 3857-3882, doi:10.5194/acp-12-3857-2012, 2012.

Zuend, A., Marcolli, C., Peter, T., and Seinfeld, J. H.: Computation of liquid-liquid equilibria and phase stabilities: implications for RH-dependent gas/particle partitioning of organic-inorganic aerosols, Atmos. Chem. Phys., 10, 7795-7820, doi:10.5194/acp10-7795-2010, 2010. 